ORIGINAL ARTICLE

AFRICAN JOURNAL OF CLINICAL AND EXPERIMENTAL MICROBIOLOGY AJCEM/201179/21203

COPYRIGHT 2012

AFR. J. CLN. EXPER. MICROBIOL 13(1): $1 \quad$ http:// dx.doi.org/10.4314/ajcem/v13i1.1

JANUARY2012 ISBN 1595-689X VOL 13(1)

-http://www.ajol.info/journals/ajcem

\title{
VIRUSES AND CANCER
}

\author{
Patrick A. Adegboyega, M.D. \\ Feist Weiller Cancer Center, Department of Pathology, Louisiana State University Health Sciences Center, \\ Shreveport, LA 711130, U.S.A. Email: padegb@1suhsc.edu
}

\begin{abstract}
Viruses are ubiquitous and are also the pathogenic agents that are most commonly associated with neoplastic transformation of cells of several organs in human beings - thereby causing cancer of epithelial cells (carcinomas) or cancer of mesenchymal cells (leukemias, lymphomas and sarcomas) depending on the type and location of the infected host cell. This review highlights the six major groups of viruses that have established aetiological association with cancer in human populations. The epidemiology and the processes through which these pathogens cause malignant transformation of the infected host cells are discussed - with particular emphasis on the evolving and changing natures of the diseases as they parallel changes in human behaviours. Also discussed is a brief overview of the current understanding of molecular pathology as they emerge with the advent of new technological capabilities for studying these processes at subcellular (genomic) levels.
\end{abstract}

\section{INTRODUCTION}

Viruses have notoriety for causing acute epidemic infections that may result in pandemics and global crisis within a short period of time. But also of an ever increasing need for attention due to the public health risk they constitute, are endemic diseases of viral origin and the associated malignancies. Viruses cause chronic infections that are endemic in many communities and such chronic infections have been shown to have aetiological associations with certain malignant disease processes that are also of endemic proportions in the affected communities. Considering the ubiquity of viruses and the high prevalence of viral infections worldwide, viruses are probably second only to tobacco abuse as the most common risk factor for developing cancer. In some cases, the development of cancer is directly related to the activities of the virus. In other cases, the virus remains dormant in host cells (carrier state) until factors such as immunosuppression and/or infection with other oncogenic viruses activates the oncogenic potentials of the virus in the carrier. This review highlights the interplay between environmental factors, host factors and viral factors that influence the oncogenic transformation of virus-infected host cells.

\section{EPSTEIN BARR VIRUS}

\section{1:1 Epstein Barr Virus (EBV) Infection and The Immune System.}

Epstein Barr Virus (EBV) is a gamma herpesvirus that was first discovered in 1964 in SubSahara Africa by Epstein, Achong and Barr when they observed and reported the presence of herpesvirus-like particles in electron micrographs of cultured Burkitt lymphoma (Burkitt's Lymphoma) cells (1). Shortly thereafter, higher titers of antibody to EBV antigens were reported in Burkitt's Lymphoma patients (2), infectious mononucleosis and undifferentiated nasopharyngeal cancer $(3,4)$. Since then, EBV has been shown to be an ubiquitous virus and the putative agent for an array of neoplastic lymphoproliferative disorders that include Hodgkin's disease, non-Hodgkin's B-cell lymphomas, immunosuppression-associated lymphomas, some T-cell lymphomas; and a subset of gastric adenocarcinoma. All these tumours have been shown to contain EBV genome and EBV-coded latent genes which play active roles in the malignant transformation of infected cells.

EBV is a linear double-stranded DNA gammaherpesvirus with global presence. It infects about $95 \%$ of adult populations in every part of the world and has a life-long persistence in infected individuals. The primary infection may be asymptomatic and occur early in life or it may occur later during pubertal years or adulthood as infectious mononucleosis $(5,6)$. Although the virus can infect epithelial cells, T-lymphocytes and B-lymphocytes, the latter are the preferred target cells (7). EBV is orally transmitted and the oropharynx is the primary site of infection and also the site for virus replication; hence, the spread of the virus through the saliva of infected persons $(8,9)$. During the primary infection of Bcells, there is an initial short-lived but critical 
burst of lytic viral replication which enhances spread of the virus to other cells and culminates in transformation of the host cells and establishment of non-productive latent infection (7). In the latency state, instead of replicating in the infected cells, the virus produces a variety of latent genes and proteins that mediate adaption of the virus to the host cells physiology to ensure survival of the virus, persistence of infection and avoidance of host immune surveillance mechanisms.

Inhibition or removal of the immune T-cells in invitro systems results in spontaneous transformation of resting EBV-infected B-cells into indefinitely proliferating lymphoblastoid cell lines (LCLs) that express high levels of B-cell activation markers (CD23, CD30, CD39 and CD70) (10); and contain multiple copies of the viral episome; nine latent proteins comprised of six EBV nuclear antigens (EBNAs) and three latent membrane proteins (LMPs). The nuclear antigens consist of EBNAs 1, 2, 3A, 3B, 3C and LP; and the LMPs include LMP1, 2A and 2B (11). EBERs 1 and 2 are small non-polyadenylated (non-coding) EBV RNAs that are also abundantly expressed in latently infected cells. Although they are not essential for transformation of EBVinfected cells into immortalized LCLs (6); they are useful as markers of latent EBV infections (5). Also identified in latently infected cells and also in EBV-associated tumours, are the BARTs (Bamh1 A rightward transcripts). These are believed to play some role in enhancing virus persistency through yet to be defined mechanism(s) (12). It appears viral persistence in host cells is enhanced and ensured through a host of mechanisms including limited expression of viral antigens during latency (> 80 antigens expressed during lytic replication compared with 9 in latency), reduced copy member of the expressed viral antigens, production of virus encoded RNAs (EBERs) which may protect EBVinfected cells from apoptosis, and use of putative latency program (latency 0) in which no detectable latency gene is expressed in the infected cells - thus rendering such infected cells invisible to the host's immune surveillance machinery (13).

Under normal circumstances, latent EBV infection is kept in check and precluded from actively spreading to infect and immortalize other host cells by a combination of $\mathrm{T}$ and $\mathrm{B}$ cell responses to the detectable EBV latent antigens. Abrogation or suppression of these host immune responses may tilt the balance in favor of active viral replication and so facilitate the development of EBV associated malignancies. Such situations may be iatrogenic immunosuppression as in transplant patients or due to co-infection by other pathogens such as Human Immunodedeficiency Virus (HIV) and Plasmodium falciparum, or local immune suppression resulting from changes in the tissue microenvironment (13).

\section{1:2 EBV and Burkitt's Lymphomas}

The discovery of EBV resulted from a striking observation that Burkitt's lymphoma was endemic in the SubSahara African region that was also holoendemic for Plasmodium falciparum infection (1). In that region, Burkitt's Lymphoma is 50 times more common compared with other regions with sporadic cases of the tumour. Also, in endemic Burkitt's Lymphoma, EBV positivity in tumour cells is $100 \%$ compared to only $15-20 \%$ in sporadic cases $(11,14)$. Burkitt's lymphoma is also common in HIV-infected patients - about $40 \%$ of AIDS-related Burkitt's lymphoma has been associated with EBV (15).

A characteristic chromosomal abnormality consistently present in all cases of Burkitt's Lymphoma is translocation of the region of $c-m y c$ proto-oncogene from the long arm of chromosome $8(8 \mathrm{q} 24)$ to the region of the immunoglobulin heavy chain gene on chromosome 14; or less commonly to the regions of the immunoglobulin light chain genes on chromosomes 2 or 22 . This results in dysregulation of the $c-m y c$ oncogene with consequent activation of pathways that favor malignant proliferation of the infected cells. $(16,17)$. EBNA1 which is the only EBV protein consistently detected in Burkitt's Lymphoma interact with the dysregulated $c-m y c$ to alter Bcell growth and so transforms the cell into a state of continuous proliferation (5).

Malaria infection causes polyclonal activation of B-lymphocytes and general immunosuppression including downregulation of EBV specific cellular T lymphocyte (CTL) response. These result in up to five-fold increase in the number of circulating EBV-infected B-cells during acute malaria infection. (18). In children with Burkitt's Lymphoma, CTL response against EBNA1 is significantly decreased while CTL responses against other EBV antigens are unaffected (19)

\section{1:3 EBV and Hodgkin's Lymphoma}

Hodgkin's lymphoma is the most common EBVassociated lymphoma in the western world with 
$18-50 \%$ EBV positivity rate in Hodgkin's lymphomas (20-22). In developing countries, the frequency of EBV associated Hodgkin's lymphoma is (much) higher and may be as high as $100 \%$ with EBV RNA and/or antigens being detected in virtually all cases in some published series, depending on the sensitivity of the assay employed $(23,24)$.

EBV having a possible casual role in the pathogenesis of Hodgkin's lymphoma was deduced from the observation of two to three fold increased risk for developing Hodgkin's lymphoma by patients with history of infectious mononucleosis (25). The first concrete evidence that showed EBV as a causative agent for Hodgkin's lymphomas was the detection of higher EBV antibodies titers in Hodgkin's lymphoma patients compared with other lymphoma patients (26), and observations that elevation of EBV antibodies titers in Hodgkin's lymphoma patients occurred several years before the development of the tumour (27).

The presence of EBV DNA in Hodgkin's lymphoma tissue samples was first demonstrated in 1987 with the use of in-situ hybridization probe. Since then, several studies have confirmed the presence of EBV DNA, RNAs and antigens in tissue samples of Hodgkin's lymphoma - using improved in-situ hybridization and immunohistochemical methods (5). Type 1 EBV is the usually detected "variant" but type 2 virus has also been reported in Hodgkin's lymphoma that develops in clinical settings of immunodeficiency. Transcripts analysis and hybridization studies have also shown clonality for EBV in Hodgkin's lymphoma tissues samples - thus confirming those tumours resulted from clonal expansion of single EBVinfected cells (28). EBV is usually associated with the mixed cellularity histopathologic form of Hodgkin's lymphoma and is more common in males, and also in pediatric patients and older patients ( $>55$ years of age) $(29,30)$.

Immunohistochemical studies and transcriptional analysis of Hodgkin's lymphoma tissue samples have shown EBV infected Hodgkin's lymphoma cells (Reed-Sternberg's cells) contain high levels of the EBV latent antigen LMP1 in the absence of EBNA2 (31-33). In the Hodgkin's lymphoma cells, LMP1 causes nuclear activation of NF-Kappa B, decrease the cell's susceptibility to apoptosis, and upregulate the production of immunosuppressive cytokines like IL-10, IL-13 and TAF-B (6,34-36). Thus EBVs
LMP1 latent antigen appears to stimulate and enhance the clonal expansion of Reed-Sternberg's cells by dysregulating the cell-cycle/apoptosis mechanisms and also by activating the cells to produce substances that have immunosuppressive effects on the microenvironment - thereby allowing the cells to escape the host's immune mechanisms (13).

\section{1:4 EBV and Immunosuppression - Related Lymphoproliferative Diseases}

EBV is also implicated as the causative agent in a number of lymphoproliferative disorders that occur in the clinical settings of immunosuppression. These include: posttransplant lymphoproliferative disorders (PTLDs), inherited immunodeficiency associated lymphoproliferative syndromes and HIV infection - related lymphomas. In these disease conditions, immunosuppressions results in unabated chronic antigenic stimulation (in the transplanted organ and also in the host patient's own tissue), enhance the activation and transformation of cells with latent EBV infection and allows the virus to escape from EBV-specific immune control mechanisms. These events combined in due course culminate in aggressive and uncontrolled proliferation of transformed EBV-infected cells.

EBV-associated HIV-related nonHodgkin's lymphomas include primary CNS lymphoma, Human herpes virus 8 (HHV8)-positive primary effusion lymphoma and it's solid variant, and plasmablastic lymphoma. Other EBV-associated lymphomas that may also occur in HIV-infected patients are diffuse large cell lymphomas with immunoblastic features and Burkitt's lymphoma (37). About $40 \%$ of AIDS associated Burkitt lymphomas are positive for EBV (15). In PTLDs and HIV-associated diffuse large cell lymphomas, majority of the cases are EBVpositive and expresses all the latent antigens (latency III) (6).

Primary effusion lymphoma (PEL) is a tumour that occurs frequently in HIV-infected patients and is very rare in immunocompetent individuals. These tumours appear to develop as a result of co-infection by EBV and Kaposi's sarcoma herpes virus - HHV8 (also a gamma herpes virus) (20). Both PEL and EBV positive HIV-related Burkitt's lymphoma express EBNA1 as the only EBV protein and both are also characterized by upregulation of $c-m y c$ oncogene 
to stimulate cell proliferation and increase resistance to apoptosis (38-40).

\section{1:5 Nasopharyngeal Carcinoma}

Undifferentiated nasopharyngeal carcinoma (UNPC; WHO type III) has a consistent global association with EBV. This tumour has a rather high incidence in Southeast Asia particularly in Southeast China and neighboring Hong Kong with a peak incidence of $20-30$ cases per 100,000 .and is the eighth leading cause of death in China (41-43). A relationship between EBV and UNPC was first suggested based on presence of high titers of EBV antibodies in UNPC patients. That was followed with in-situ demonstration of EBV DNA and EBNA proteins in the tumour cells (4). Also, EBV genomes in UNPC tumour cells have been shown to be monoclonal, suggesting the tumour results from clonal proliferation of cells with latent EBV-infection (44).

Irrespective of geographic location, UNPC is invariably positive for EBV with a $100 \%$ positivity rate (45-47). EBNA1 and EBERs are detected in $100 \%$ of cases and LMP1 in up to $65 \%$ cases depending on the sensitivity of the assay $(48,49)$. Elevation of $\operatorname{IgA}$ titers against EBV antigens may occur several years before development of UNPC. The antibody titer also correlates with tumour burden, remission and recurrence $(50,51))$. Therefore, EBV-specific serology (titers of IgA antibodies to EBV capsid antigen and early antigens) is now employed as invaluable tool in the management of UNPC for diagnosis and monitoring of response to therapy $(52,53)$.

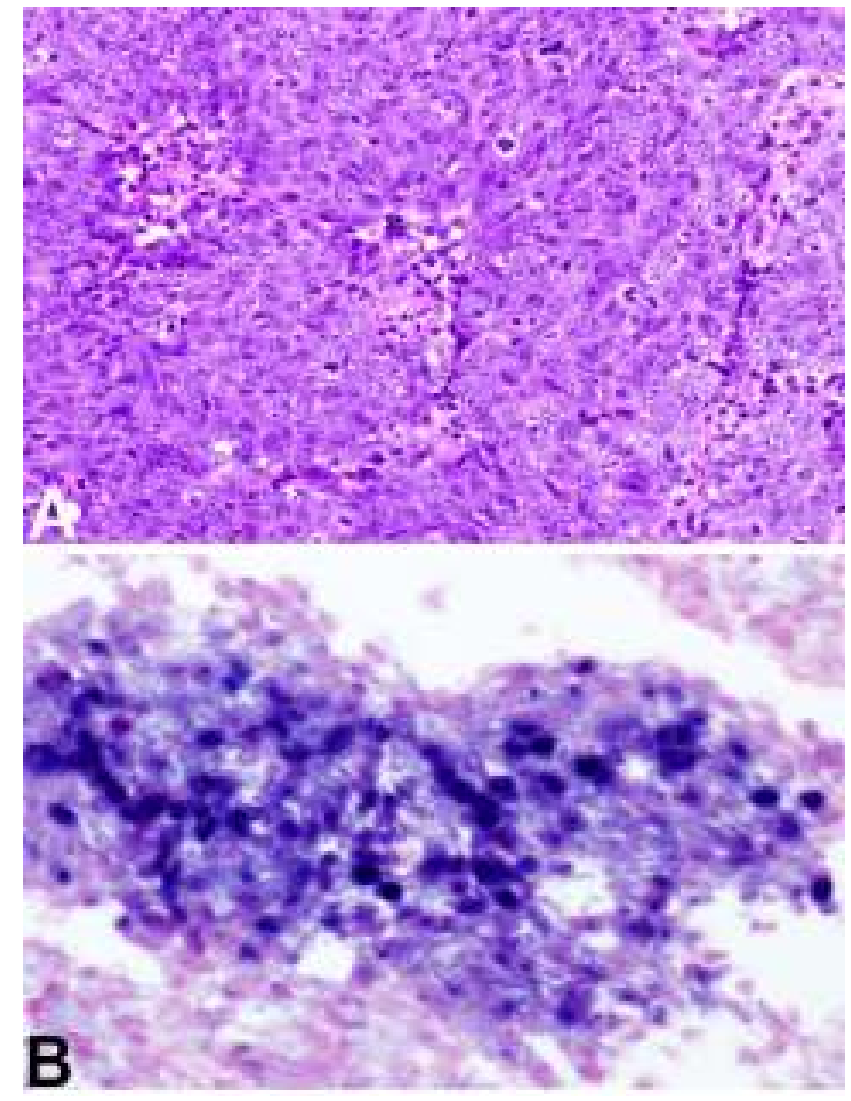

Figure 1

A. Hematoxylin and Eosin-stained tissue section micrograph of EBV-associated nasopharyngeal undifferentiated carcinoma.

B. In-situ hybridization showing presence of EBER in the tumour cells. 
In addition to EBV infection, other non-viral factors contribute to the development of UNPC in affected individuals. These include genetic predisposition, consumption of salted fish and meats containing the preservative nitrosamine and a prolonged exposure to domestic wood cooking (for at least 10 years) $(43,50)$. The report of high incidence rates of this tumour in individuals of chinese descent (especially Cantonese males) that are residents in other parts of the world that are not endemic for EBV infection, suggests genetic predisposition as a key underlying factor for the development of EBVassociated nasopharyngeal carcinoma (5).

\section{1:6 EBV and T-cell lymphomas}

Although B-cells are the preferred cells for EBV infection, the virus can also infect CD4+ and CD8+ T-cells and Natural Killer (NK) cells (54). A number of EBV-associated T-cell/Natural Killer cells lymphoproliferative disorder have been reported; the most common of these is sinus-nasal T-cell nonHodgkins lymphomas (SNTL). SNTL have been reported in Asia, Europe, North and South America and do not appear to have distinctive geographical or racial distribution (55). These tumours characteristically express NK markers, may lack $\mathrm{T}$-cell antigens and do not express $\mathrm{T}$-cell receptor gene re-arrangements. In in-vitro experimental settings, T-cells are refractory to EBV infection; therefore the exact mechanism(s) of how EBV infects T-cells and participate in development of $\mathrm{T} / \mathrm{NK}$ cells lymphoma is still an enigma (15).

Since most EBV-associated T-cell lymphomas develop in the context of chronic active EBV infection (of B-cells), there are suggestions that EBV-associated T-cell oncogenesis may be a result of proliferating cytotoxic T-cells trying to kill the EBV infected cells. This assertion is supported by the fact that most EBV-associated T-cell lymphomas have cytotoxic phenotype (positive expression of granzyme $\mathrm{B}$ and T-cell intracytoplasmic antigen-1 [TIA1]). Type II latency (expression of EBNA1 and LMP 1, 2A and $2 \mathrm{~B}$ ) is characteristic but interestingly, EBV is detected only in a fraction (5-50\%) of tumour cells - implying EBV infection may have occurred after development of the tumour (56). EBV-infected B cells with type III latency are frequently detected in T-cell lymphomas and may contribute to the neoplastic T-cells through secretion of tumour-enhancing cytokines or direct stimulatory interactions with the T-cells (6).

\section{1:7 EBV and Gastric Carcinoma}

EBV-associated gastric carcinoma is defined by the presence of EBV in the tumour cells irrespective of the histologic appearance of the tumour. In 1990, Burke et al using PCR-based detection method, reported the presence of EBV genome in a group of gastric carcinoma characterized by a lymphoepithelioma-like histologic appearance (57). Subsequent studies with in-situ hybridization in the 1990s reported the abundant presence of monoclonal EBV (positive EBER signals) in a subset of gastric adenocarcinoma including those that lack the lymphoepithelioma-like histomorphology. The studies also showed the abundant presence of EBER in virtually all tumour cells; and none in surrounding benign epithelial cells (58-61). Also suggesting possible etiological role for EBV in these tumours is the presence of elevated titers of EBV prior to the diagnosis of EBV-associated gastric carcinoma (62). According to pooled (meta-analysis) data from America, Asia and Europe, about $10 \%$ of gastric carcinomas are associated with EBV (63).

In-situ hybridization has also shown the virus (EBER signals) to be present in the tumour cells at all stages - from pre-invasive intramucosal to invasive stage. Genomic terminal repeat studies have confirmed the monoclonality of the EBV in the tumour cells and also showed EBV infection in the tumour cells is latent (with no active viral replication); and that the virus exist in the tumour cells in unintegrated (episomal) forms $(59,61,64)$. These data taken together show EBV infection and its role in neoplastic transformation of gastric epithelial cells occur early in the premalignant stage.

Unlike EBV-associated undifferentiated nasopharyngeal carcinoma which is characterized by intense stromal lymphocytic infiltrate, the overwhelming majority (about 80\%) of EBV-associated gastric carcinoma has notably less but varying degrees of lymphocytic infiltrate - i.e. akin to what obtains with regular gastric carcinomas. However, irrespective of their histomorphologic appearance, all EBV-associated gastric carcinomas share the following clinicopathologic features: They occur predominantly in males, relatively younger patients and unlike Helicobacter pylori-associated carcinomas, tend to be localized to proximal regions (cardia and body) of the stomach. Compared with regular gastric carcinomas, EBV- 
associated tumours also tend to have relatively better prognosis with lower rate of lymph node metastasis $(65,66)$.

Exactly how EBV infects gastric mucosa epithelial cells and establishes latency therein is still a matter of speculation. However, in-situ hybridization studies have shown EBV infected epithelial cells in the fundic glands to be the likely nidus of the viral infection that eventually results in malignant transformation of the epithelial cells. In the infected cells, EBV through its oncoproteins (LMP1 and LMP2A), causes global non-random aberrant ( $\mathrm{C} \rho \mathrm{G}$ island) methylation of the promoter regions of several oncogenes such as p14, p16, p73, CDH1 and PTEN (57,60,67). Carcinoma with Lymphoepithelima-like histologic appearance has been reported in other organs including liver, oral cavity and breast, but EBV has not been conclusively associated with any of these tumours.

\section{CHRONIC VIRAL HEPATITIS AND HEPATOCELLULAR CARCINOMA}

\section{2:1 Viral Hepatitis and Hepatocellular Carcinoma}

Hepatocellular carcinoma is the fifth most common cancer and the third leading cause of cancer related deaths worldwide (68). The incidence of hepatocellular carcinoma is rising in the western world. In the United States of America, both the incidence of hepatocellular carcinoma and rate of cancer-related death due to hepatocellular carcinoma is on the rise, even though the overall rate of cancer deaths is declining. This paradoxical situation has been attributed to an increase in $\mathrm{HBV}$ related hepatocellular carcinoma among immigrants from endemic countries and also partly to an increase in the incidence of hepatitis $C$ infection in the American populace (69) in which up to two thirds of hepatocellular carcinoma are related to chronic $\mathrm{HCV}$ infection (70)

Infection with hepatitis B virus (HBV) and hepatitis $C$ virus $(\mathrm{HCV})$ is the number one risk factor for hepatocellular carcinoma worldwide, with these viral infections accounting for over $80 \%$ of all hepatocellular carcinoma cases globally (71). The remaining $20 \%$ of hepatocellular carcinoma is attributed to other risk factors such as alcohol consumption, aflatoxin B1, and other chronic liver disease such as non-alcoholic fatty liver disease, and inherited metabolic diseases (hemochromatosis and alpha one antitrypsin deficiency) (69).

\section{2:2:1 Hepatitis B Virus and Hepatocellular Carcinoma}

The association of hepatocellular carcinoma with chronic hepatitis B infection was first noted in 1970 and confirmed by subsequent studies in the following two decades leading to the established and now undisputed fact that more than $80 \%$ of patients with hepatocellular carcinoma reside in high incidence areas (East Asia and Sub-Saharan Africa) where more than $80 \%$ of patients with hepatocellular carcinoma were seropositive hepatitis B surface antigen (HBsAg), compared with $10-15 \%$ positive rate in control populations. Also, serologic evidence of active or previous HBV infection evidenced by positive hepatitis B core antigen (serum positivity) has been reported in more than $90 \%$ cases of hepatocellular carcinoma (69). A definite aetiological association of HBV with hepatocellular carcinoma was reported in 1981 by Beasley et al (72) following their large prospective cohort study of 22,707 male municipal workers in Taiwan between 1975 and 1980. 3,454 (15.2\%) were seropositive for $\mathrm{HBsAg}$ with 40 of them dying from hepatocellular carcinoma compared with only one hepatocellular carcinoma -related death among the 19,253 HBsAg seronegative participants. The incidence of hepatocellular carcinoma among the HBsAg carriers was 1,158 per 100,000 compared with $5 / 100,000$ in their seronegative counterparts; and a calculated relative risk of 223 for hepatocellular carcinoma developing in seropositive individuals. A more recent and larger prospective cohort study involving 90,000 participants and including $11,000 \mathrm{HBs} A g$ positive patients followed over a period 8 years, showed that hepatitis B virus infected patients have 18.8 and 33.2 risk for hepatocellular carcinoma in men and women respectively (73). These studies and others have proven unequivocally, the association between hepatitis B virus infection and hepatocellular carcinoma.

Another direct evidence of causative linkage between hepatitis B infection and hepatocellular carcinoma is the relationship between level of serum HBV DNA (marker of HBV replication) and the risk of hepatocellular carcinoma. Several studies have shown that there is a direct relationship between serum levels of HBV DNA and risk of hepatocellular carcinoma; with 
elevated baseline serum level of HBV DNA greater than 10,000 copies per $\mathrm{mL}$ (approximately $2,000 \mathrm{IU} / \mathrm{mL}$ ) being a strong predictor of subsequent development of hepatocellular carcinoma. This association has also been shown to be independent of serum Hepatitis B e antigen (HBeAg) status, serum aminotransferases levels, or the presence of cirrhosis $(74,75)$. Serum positivity for $\mathrm{HBeAg}$ was previously considered to be a risk factor for development of hepatocellular carcinoma. However, subsequent studies have not shown it to be an independent predictor of development of hepatocellular carcinoma. It is now thought it effects may be dependent on the underlying levels of HBV DNA in the serum as well as the genotype of the HBV involved $(74,76)$. There is a definite association between certain types of $\mathrm{HBV}$ genotypes and higher risk and rate of hepatocellular carcinoma. Of the eight known HBV genotypes (A-H), based on genomic sequence divergence, $\mathrm{HBV}$ genotype $C$ infected patients are generally believed to have increased risk of developing hepatocellular carcinoma compared with patients infected with other genotypes $(75,77)$. HBV genotype $C$ has also been associated with poorer surgical outcomes and higher hepatocellular carcinoma recurrence rate following surgical resection of the primary tumour. This is probably due to the higher pathogenicity of this genotype - as the patients tend to have more active disease in the residual liver (78). However, a few studies have also shown that in some populations, genotype B or even genotype $\mathrm{F}$ may be associated with higher risk for developing hepatocellular carcinoma (79)

\section{2:2:2 Hepatits B Virus and Viral Hepatocarcinogenesis}

Hepatitis B virus is a double stranded DNA virus that belongs to the Hepadnavirus family. The virion has a diameter of 42 nanometer $(\mathrm{nm})$ and is composed of an outer envelope formed by hepatitis B surface antigen surrounding an inner nucleocapsid, the hepatitis core antigen, which contains the viral genome and polymerase (68). The process through which HBV causes oncogenic transformation of infected hepatocytes is yet to be fully elucidated. It involves a complex multistep process involving the activation of cellular oncogenes, the inactivation of tumour suppression genes, and dysregulation of multiple signal transduction pathways that are critical to control of cell proliferation and viability, apoptosis, and cellular DNA repair mechanisms.
Although, HBV can replicate on its own without integrating into the HBV DNA, its integration into the host genome does allow for persistence of the viral genome within the host cells (80). It appears HBV causes hepatocellular carcinoma principally through the integration of its DNA into the host genome. Integration of HBV into the genome as evidenced by the presence of $\mathrm{HBV}$ DNA in tumour cells has been found in about $80 \%$ of HBV related hepatocellular carcinoma. HBV DNA has also been found to be integrated into non hepatocellular carcinoma tissue, but the DNA in individual hepatocellular carcinoma has been shown to be monoclonal in nature, thus supporting the observation that HBV DNA integration is a critical aetiologic factor in those tumours (81). HBV DNA integration into the host genome has been found to occur at both critical and non-critical locations and appears to occur in a random manner with marked variation in the length and the components of the integrant HBV DNA (82). The integration of HBV DNA into the host cell genome results in several mutagenic events that culminate in chromosomal instability and malignant transformation of affected cell (80). Integration of HBV induces a host of genetic alterations within the host genome including chromosomal deletions, translocations and upregulation of genetic mechanisms responsible for maintaining cellular homeostasis and general genomic stability (68).

A number of $\mathrm{HBV}$ genes and their products (proteins) have been implicated in HBV-related hepatocarcinogenesis. These include $H B x$ gene, pre-s2/s gene, and the HBV spliced protein. Of these, $H B x$ gene has been shown to be the most important and also the most commonly integrated gene - being present in over $90 \%$ of HBV-related cirrhosis and dysplasia; and in 70\% of HBV related hepatocellular carcinoma (80).

Integration of the $H B x$ gene into host DNA results in transcriptional activation of several cellular genes associated with growth control (83), and promotion of host genetic instability through a variety of mechanisms that include compromise of host cell nucleotide excision repair (DNA repair) mechanisms, inactivation of p53 (a tumour suppressor gene) and disruption of p53-associated DNA repair pathways. $H B x$ also transactivates several cytoplasmic signaling pathways in ways that further compromise cellular proliferation and differentiation - with the balance tilted towards enhanced proliferation and decreased apoptosis (68). HBx has also been shown to be a factor in promoting TGF-beta mediated fibrosis, thus promoting development 
of cirrhosis in HBV infected patients. Animal models studies also provide evidence supporting the role of $H B x$ in hepatocarcinogenesis. It has been shown for instance, that woodchucks animal models in which $H B x$ gene is present and integrated into the host genome develop hepatocellular carcinoma within 3-4 years following infection; whereas, duck hepatitis B virus infection in which the virus lacks the $H B x$ gene never results in the development of cancer in infected ducks (84).

\section{2:2:3 Hepatitis B Viral Hepatocarcinogenesis} and Cirrhosis

Although hepatitis B virus may cause hepatocellular carcinoma directly without cirrhosis, it appears that the high propensity of the virus to cause hepatocellular carcinoma is due to the virus's ability to induce cirrhosis in the liver. Between $70-80 \%$ of HBV related hepatocellular carcinoma occur in cirrhotic liver with the risk of cirrhosis being greater in older patients $(69,80,85)$. Cirrhosis irrespective of its aetiology, is known to be associated with increased risk for hepatocellular carcinoma. 80$90 \%$ of all hepatocellular carcinomas develop in cirrhotic liver (86). Liver cirrhosis develops in 20 $30 \%$ of patients after 20-30 years of chronic infection and hepatocellular carcinoma develops at an annual of $1-7 \%$ in HCV infected cirrhotic patients and $3-8 \%$ in $\mathrm{HBV}$ infected cirrhotic patients $(68,87,88)$. This may explain in part, the higher incidence of HBV associated hepatocellular carcinoma in HBV endemic regions (sub-Saharan Africa and East Asia). In those regions, $\mathrm{HBV}$ is acquired at birth or early in life (through maternal-infant transmission), with consequent high rate of lifelong chronic infection (that is often unabated) and eventual evolution of the disease into cirrhosis and hepatocellular carcinoma; compared with western populations where hepatitis B infection is usually acquired during adolescence or adulthood (commonly through sexual contact).

Since HBV infection is the major aetiologic risk factor for hepatocellular carcinoma globally, the most effective way of preventing and controlling hepatocellular carcinoma secondary to HBV infection is to prevent $\mathrm{HBV}$ infection and so reduce the seroprevalence of $\mathrm{HBV}$ in the general population. Use of HBV vaccination (large scale national programs of vaccination against of hepatitis B) in many countries has proven to be an effective way (cost effective and efficient way) of achieving this objective. The resultant decrease in hepatitis B infection and HBV related cirrhosis has resulted in marked reduction in the incidence of childhood HBV related hepatocellular carcinoma and it is expected that this would also later transform to reduction in the incidence and prevalence of $\mathrm{HBV}$ related hepatocellular carcinoma as the vaccinated children populations grow into adulthood (69). Also, since high level of serum of HBV DNA has been shown to be associated with increased risk of hepatocellular carcinoma, aggressive and effective use of antiviral therapy of hepatitis B infection is another practicable way of preventing $\mathrm{HBV}$ related hepatocellular carcinoma (89).

\section{HEPATITIS C VIRUS HEPATOCELLULAR CARCINOMA}

$\mathrm{HCV}$ is an RNA virus and belongs to the Flaviviridae family. It has an open reading frame that encodes a single polyprotein which is processed into both structural (core and envelope) and non-structural proteins. Patients infected with HCV have 11.5 to 17 fold increased risk for developing hepatocellular carcinoma $(90,91)$.

In the host cells, HCV being an RNA virus is unable to integrate itself into the host genome. Therefore, the viral RNA genome is replicated and packaged into new viral particles in the cytoplasm of host cells through the combined machinery of viral and host proteases. The associated translation of viral protein results in host responses that facilitate oncogenic (malignant) transformation of the host cells. $\mathrm{HCV}$ core protein has been shown to be the most important factor in $\mathrm{HCV}$-induced hepatocarcinogenesis (68). The envelope proteins (E1 and E2) appear to have synergistic effects in accelerating tumour development. When treated with Diethylnitrosamine, transgenic mice expressing core protein, E1 and E2 envelope proteins develop tumours faster than mice expressing only core protein (92). This recent finding confirms earlier reports that in transgenic mice, the presence of the complete $\mathrm{HCV}$ polyprotein enhances hepatocellular carcinoma development in a more efficient manner compared with the presence of structural proteins alone (93). In the absence of structural proteins, HCV non-structural proteins do not cause any known liver pathology (94).

The exact molecular mechanism through which $\mathrm{HCV}$ induces hepatocarcinogenesis is yet to be fully understood. HCV proteins induce 
hepatocarcinogenesis through a combination of complex and sometimes overlapping molecular events that ultimately result in suppression of apoptosis, and enhancement of proliferation of the infected hepatocytes. This is done mainly through modulation of p53 and p53 dependent pathways, such as those mediated by p21, p73 and $\mathrm{pRb}$; and results in derangement of cell cycle control mechanisms (68). HCV core protein through Smad3 activation reverses TGF-Beta cell growth-suppressing effect to tumour-promoting responses in the infected cells (95). In addition, by upregulating TGF-Beta, HCV core protein induces fibrogenesis, causing liver cirrhosis and therefore increasing the risk of hepatocellular carcinoma (96).

$\mathrm{HCV}$ infection is also associated with steatosis and that has been shown to occur in as high as $70 \%$ of patients with chronic HCV infection (97). Steatosis worsens fibrosis and accelerates the development of cirrhosis and is also an independent high risk factor for the development of hepatocellular carcinoma in $\mathrm{HCV}$ infected patients (98). HCV induced steatohepatitis and fibrogenesis result from increased oxidative stress and lipid peroxidation. These result in generation of radical oxidative species (ROS) and consequent oxidative DNA damage, increased chromosomal instability, chromosomal aberrations and eventually, oncogenic transformation of the host cell.

Patients with chronic hepatitis infection often have elevated serum iron and increased hepatic iron deposition. Free iron in hepatocytes cytoplasm results in increased oxidative stress and so enhances lipid peroxidation and also facilitates fibrogenesis and development of cirrhosis (99-101).

In summary, chronic HCV infection is associated with three distinct pathologic events that are associated with increased risk of hepatocellular carcinoma, viz: steatosis, hepatocytic accumulation of iron and cirrhosis.

\section{HUMAN HERPES VIRUS 8 (KAPOSI'S SARCOMA-ASSOCIATED HERPES VIRUS)}

Kaposi's sarcoma (KS), a multicentric tumour of endothelial cells was first described in 1872 by Moritz Kaposi as "idiopathic multiple pigmented sarcoma of skin" that affects elderly Jewish men of Ashkenazi origins and was later named Kaposi's sarcoma (KS) by Koebner in 1895. During the 1940s through 1980, endemic KS was described in parts of Central and East Africa
(Uganda, Malawi and Kenya) where it most commonly affects children and presents with disseminated lymphadenopathy, hence the designation lymphadenopathic KS (102,103). In 1969, the first case of KS occurring after an organ transplant was reported (104) and thereafter, it has been established in the literature that iatrogenic KS occurs in immunosuppressed individuals such as organ transplant patients 105). In 1981, report of KS epidemic affecting young homosexual men in the USA was the first indicator of a soon to-be-discovered HIV1 infection pandemic (106-108). As of today, KS is the most common neoplasm in untreated HIV infected patients; and remains the most common AIDS-associated cancer in both developed and developing countries (109). In the western world, it continues to be most prevalent among HIV-infected homosexual men; whereas, in Africa, due to sexual practices that may include multiple sexual partners in heterosexuals and bisexual individuals, HIV-related KS epidemic is common among both male and female genders (110).

The incidence of KS in the general population is 1 in 100,000, 1 in 20 in HIV-infected individuals and was as high as 1 in 3 in HIV-infected homosexual men before the introduction of highly active antiretroviral therapy (HAART) $(111,112)$. Due to lack of adequate or appropriate treatment of HIV infection, about $90 \%$ of all KS cases now occur in Sub-Saharan Africa and only about $12 \%$ of patients are alive five years after diagnosis $(110,113,114)$. In the developed countries, the advent and success of HAART led to a dramatic drop in the incidence and mortality of HIV-related KS $(115,116)$

Since the 1950s, an infectious agent has been suspected to cause KS. Herpes viral particles in tissue culture of KS lesional cells were demonstrated by electron microscopy in 1972 (117). However, it was much later (in 1990) following the emergence of HIV/AIDS pandemic that an infectious agent was proposed as the etiologic factor for KS (112). In 1994, a definite association was established between a new human gamma herpes virus and KS through isolation and characterization of DNA fragments obtained from KS tissue biopsy specimens. In that study, the new herpes virus DNA sequences were isolated from more than $90 \%$ of $\mathrm{KS}$ tissues and $15 \%$ of non-KS tissues of AIDS patients and in none of the tissue samples from non-AIDS patients (118). The new virus was named Kaposi's Sarcoma-associated Herpes Virus 
(KSHV - now also known as Human Herpes Virus 8 \{HHV8\}). HHV8 latency associated nuclear antigen (LANA) is expressed in all cells infected by the virus and irrespective of the underlying clinical condition, over $95 \%$ of KS have been found to be infected with this virus (119). The immunohistochemical detection of the viral latency protein (LANA) has become a useful tool in the histopathologic diagnosis of the tumour using light microscopy $(120,121)$. The strong association of KS epidemic with the HIV infection pandemic eventually resulted in the identification of KS as an AIDS-defining illness in HIV-infected patients (122).

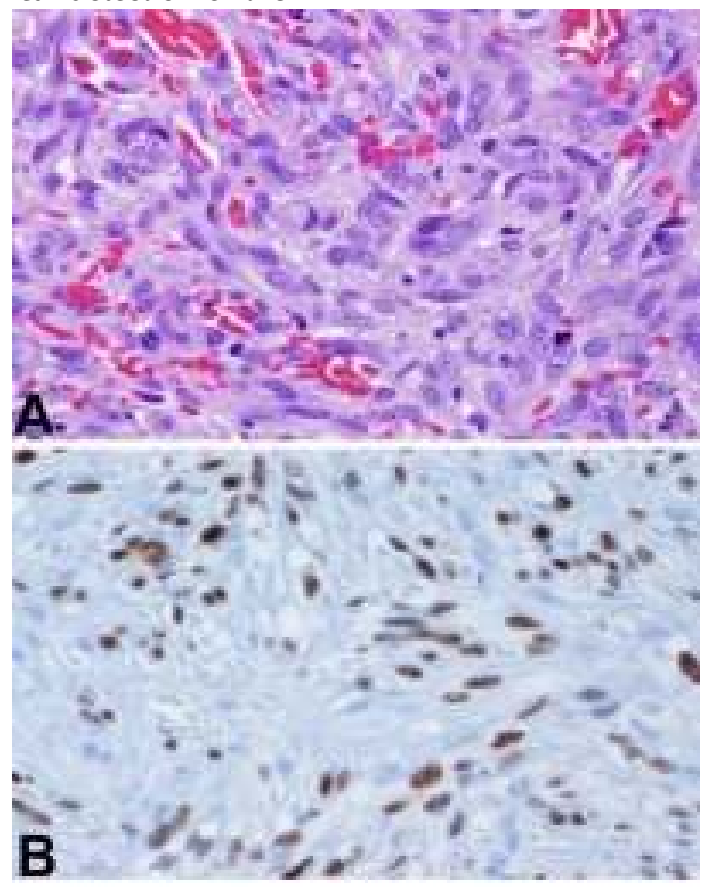

Figure 2

A. Kaposi's sarcoma with spindle cell proliferation of endothelial cells.

B. Positive immunohistochemical staining for HHV8 in the nuclei of the tumour cells.

Iatrogenic KS (also known as post-transplant KS) is immunosuppression-associated KS that occurs in transplant patients who receive solid organs such as kidney, pancreas and heart; and it is most common in renal transplant patients (123). In this group of patients, long-term immunosuppression which is essential for preventing allograft rejection creates a microenvironment that is conducive for KSHVinduced malignant transformation. Fortunately, this form of KS usually resolves with withdrawal or reduction of the immunosuppressive therapy.

In addition to KS, two highly aggressive and rapidly fatal non-Hodgkin's B-cell lymphomas have also been associated with KSHV. These are (1) primary effusion lymphoma (PEL) - a tumour that is also very common in HIV-infected patients with AIDS (124) and (2) plasmablastic lymphoma arising in patients with multicentric
Castleman's disease, especially in those who are also HIV positive $(125,126)$.

Oncogenetic transformation of endothelial cells and infected B lymphocytes by KSHV occurs through a complex multistep process that may result in genomic chromosomal instability, alternation of cell cycle and programmed cell death regulatory genes, increase in cell proliferation and long-term survival, and upregulation of cells' invasive properties (103). KSHV like other herpesviruses has a double stranded DNA genome and possesses a long unique region in which 15 unique open reading frames (ORFs) are located. These are designated sequentially $\mathrm{K} 1$ through $\mathrm{K} 15$ based on their relative locations in the KSHV genome and are involved in signal transduction, cell cycle regulation, inhibitions of apoptosis and immune modulation. The virus also possesses some microRNAs (a total of 12 discovered so far); they 
play critical roles in KSHV pathogenesis (103). KSHV has a two-phased life cycle that is typical for herpesviruses. The lytic phase characterized by active replication of linear viral genomes and production of immediate early $(\alpha)$, early $(\beta)$ and late $(\gamma)$ transcripts and an episomal latent phase during which the virus exist in the host cell as circularized extrachromosomal viral genome - a state in which no infectious or functional viral particles are produced. This state of latency is established and maintained principally by the latency nuclear antigen (LANA) (127-129). LANA and other viral proteins interact with p53 and other cell cycle regulatory proteins and as a result derange a host of cellular pathways involved in cell proliferation, programmed cell death and tumourigenesis $(103,130)$.

\section{HUMAN PAPILLOMA VIRUS}

\section{5:1 HPV and Human Cancers - Historical Account}

A probable relationship between cervical cancer and sexually transmitted agents was first noted in 1842 by Rigoni-Stern who reported a high frequency of cervical cancer in married women, widows, and prostitutes; but rare in virgins and nuns (131). With the advent of better bacteriology and virology techniques in the latter part of the 20 th century, in the late 1960's and early 1970's, a number of investigators reported Herpes simplex virus type 2 as the likely causative agent for sexual disease - related cervical cancer. But large scale prospective studies exonerated Herpes simplex type 2 virus as the likely candidate (132).

In the late 1970s and early 1980s, Vonka et al $(133,134)$ conducted a large prospective study in attempts to establish a relationship between Herpes simplex type 2 virus and its causative role in cervical neoplasia. In a study conducted over 8 years (1975 to 1983), 10,683 women were enrolled and 10,389 had complete set of data. In the subset of women with moderate to severe squamous dysplasia, squamous cell carcinoma in situ and invasive squamous cell carcinoma either at enrollment or during the follow-up period, the prevalence of Herpes simplex type 2 virus antibody was the same as in control women

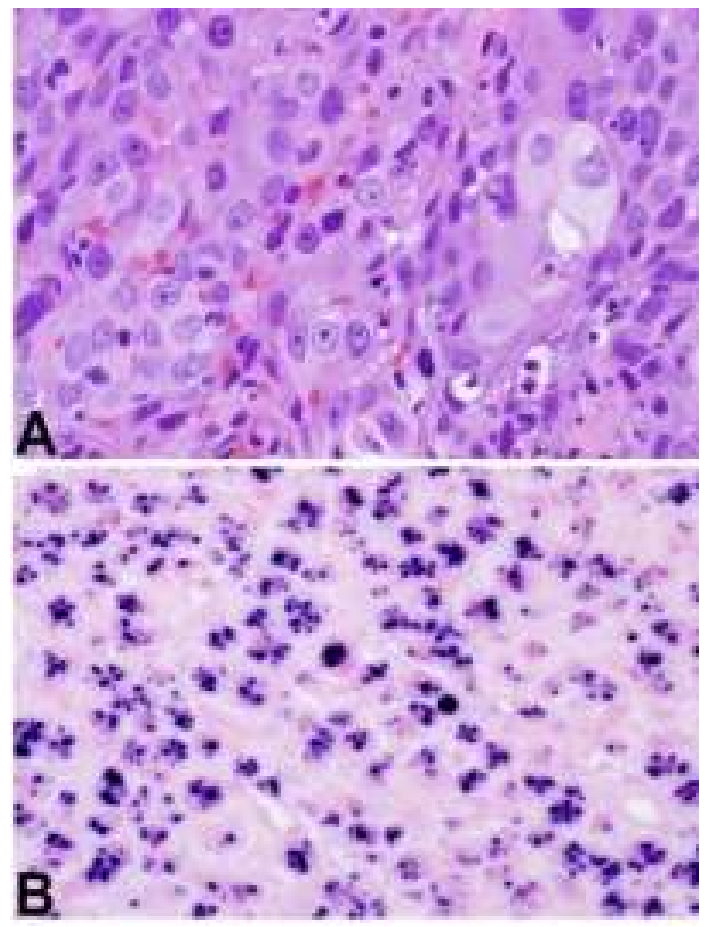

Figure 3

A. Hematoxylin and Eosin-stained tissue section micrograph of HPV-associated squamous cell carcinoma of the oropharyngeal.

B. In-situ hybridization showing presence of HPV in the nuclei of the tumour cells with diffuse and dot like staining patterns. 
appropriately matched by age, age at first intercourse, number of sexual partners, smoking habits and clinical integrity of the cervical ectopic epithelium (ectocervix) and the transformation zone. That landmark report was followed by intense investigation and search for the culprit pathogenic agent and eventually led to the identification and confirmation of Human Papilloma Virus (HPV) as the causative agent. In the 1970's, there were anecdotal reports of association between HPV induced genital warts (Condyloma acuminata) and cervical cancer. In 1982, the presence of HPV DNA in invasive squamous cell carcinoma was reported (135) and soon confirmed by additional reports in the following year. That was followed by a burst of additional confirmatory epidemiological, histopathologic and molecular data in the years that follow $(136,137)$. Today, there are more than 200 known types and $20 \%$ of them known to cause human infections.

\section{5:2 HPV and Anogenital/Uterine Cervical Cancers}

Cervical cancer is the second most common cancer in women worldwide with about 500,000 new cases and 274,000 cervical cancer deaths occurring each year (138). A disproportionately high percentage of these new cancer cases and deaths (about $80 \%$ ) occur in developing countries (138). There is an abundance of epidemiological and experimental data that show HPVs have causative roles in genital as well as extragenital mucocutaneous squamous cell carcinomas. HPVs are the most sexually transmitted viruses, the most prevalent viruses implicated in causing cancer in human populations and second only to tobacco usage as most important risk factors for developing cancer in human beings (139).

HPV has now been shown to be the causative agent in almost $100 \%$ of cervical cancer, and is also responsible for about $50 \%$ of vulva squamous cell carcinoma (140), 30 to $50 \%$ of penile carcinomas (141-143), 60 to $90 \%$ of vaginal carcinomas $(140,144)$ and also with a similar percentage for anal and perineal cancers (145). A large study of cervical cancer material collected from patients in 22 countries all over the world revealed HPV genome in $99.7 \%$ of cases (144).

A recent Medline review of 1,824 cases from 37 studies using PCR or hybrid capture for HPV detection in anal squamous dysplasia and invasive carcinoma shows the prevalence of HPV 16 and 18 to be $90 \% \quad(n=832)$ in squamous dysplasia and about $70 \%$ in invasive carcinoma $(\mathrm{n}=992)$; similar to the prevalence observed in invasive cervical cancer (146). A similar review of HPV distribution in vulvar and vaginal cancers show an HPV prevalence of $40 \%$ in invasive vulvar carcinoma $(n=1379)$ and about $80 \%$ in vulvar squamous dysplasia; and a much higher rate in the vaginal cancers and premalignant (dysplastic) vagina epithelium $65 \%$ and greater than $90 \%$ respectively (147).

Meta-analysis of pooled data on HPV type distribution and prevalence between 1990 and 2010 and including 243 studies with a total of 30,848 cases of invasive cervical cancer showed a steady increase from $85.9 \%$ in the 1990 s to $92.9 \%$ in studies published between 2006 and 2010. The prevalence of HPV 16 and/or 18 was $82 \%$ in Western/Central Asia and 68\% in Eastern Asia (148). In recent study of uterine cervix squamous dysplasia (premalignant lesions that predate HPV induced invasive carcinoma), HPV was detected in $98.4 \%$ of women $(n=643)$ with more than half of them $(52.5 \%)$ infected with more than one HPV serotype; and HPV 16 was the most commonly detected type. Other HPV types detected include HPV 31, 33, 52, 18 and 51 (149). A multisite study of HPV types specific prevalence in women with cervical cancer and premalignant intraepithelial changes in the cervix in England and involving 6,234 women showed the prevalence of HPV 16 and/or 18 to be $76 \%$ in squamous cell carcinomas, $82 \%$ in adeno/adenosquamous carcinoma and $63 \%$ and $91 \%$ respectively in severe cervical squamous intraepithelial dysplasia and cervical glandular intraepithelial neoplasia (150).

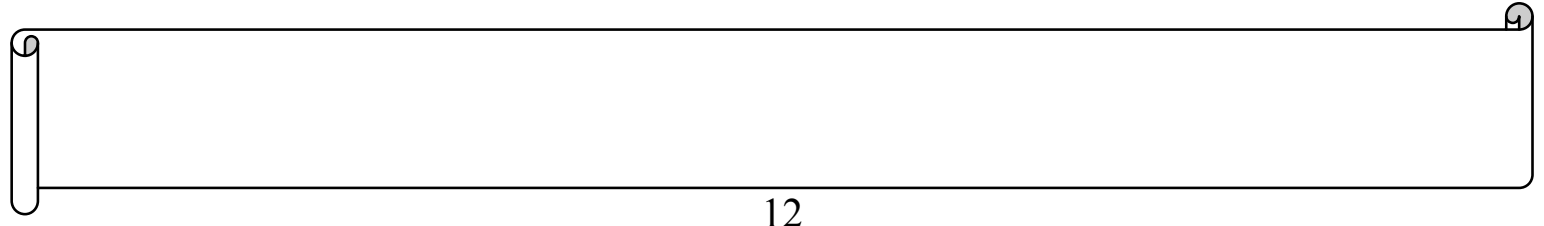




\section{5:3 HPV and Cancer of the Head and Neck Region}

The first evidence of HPV involvement as causative agents of oropharyngeal cancers was first reported in 1983 by Syrjanen et al (156) when they showed the presence of positive immunoperoxidase staining for HPV in oral epithelial hyperplasia and squamous cell papillomas. That was followed by a report of specific HPV types in cancer of the tongue and oropharyngeal region (157). Subsequent studies have since confirmed the association of HPV with cancer of the head and neck regions especially that of the oropharyngeal region with rate of positivity varying between 25 to $60 \%(132,158)$. It is now conservatively estimated between 25 to $30 \%$ of oropharyngeal cancers are caused by HPV and that the virus does have some aetiological role in these tumours (132). There is increasing incidence of oropharyngeal, tongue base and tonsillar cancer in the young men and women in the United States and evidence abounds that $\mathrm{HPV}$ infection is the underlying aetiological factor (159).

In a multicenter case control study involving 9 countries, it was shown that HPV is involved in significant proportion of oropharyngeal cancers and in a smaller group of squamous carcinoma of the oral cavity. Also in that study, it was found that $70 \%$ of the tumours contain HPV DNA with HPV 16 as the most frequently observed; a scenario that is similar to that observed in HPVrelated genital cancers (160). Studies using very reliable techniques (quantitative PCR and in-situ hybridization) have shown that HPV occur in only a small proportion of oral cavity squamous cell carcinoma and in up to $60 \%$ of oropharyngeal tumours (161,162). Kreimer, AR et al (163) reviewed published studies that employ PCR based method to detect and genotype HPV in order to describe the prevalence and HPV type distribution by anatomic cancer sites and geographic location, as possible source of variability. With a total of 5,046 cases of squamous cell carcinoma from 60 eligible studies from 26 countries, the overall HPV prevalence in head and neck cancer was reported as $25.9 \%$ and HPV prevalence was significantly higher in oropharyngeal squamous cell carcinoma $(35.6 \%$ compared to $23.5 \%$ in oral squamous cell carcinoma and $24.0 \%$ in laryngeal squamous cell carcinoma). HPV 16 accounted for the majority of HPV positive oropharyngeal carcinoma (86.7\%) compared with $68.2 \%$ and $69.2 \%$ in HPV positive oral and HPV associated laryngeal squamous cell carcinoma. HPV 18 which is the second most common detected high risk type was found in only very small number of cases. HPV 18 detection rate was $8 \%, 3.9 \%$ in oral and laryngeal cancers and only $1 \%$ oropharyngeal cancers. HPV prevalence in oral squamous carcinoma was found to be similar in Europe and North America (16 and 16.1\% respectively) but was significantly greater in Asia (33\%). However, with oropharyngeal carcinoma, HPV prevalence was significantly higher in North America (47\%) compared with Europe (28.2\%). In the cases from Asia, the HPV prevalence rate for oropharyngeal carcinoma was rather high (46.3\%) but the number of cases studied was very small $(n=54)$. Thus in all, HPV prevalence in oral squamous cell carcinoma from Asia was considerably higher than other geographic locations and HPV prevalence was higher in oropharyngeal squamous cell carcinoma from North America and Asia compared with Europe (162). However, in a multicontinent study conducted by IARC, HPV prevalence did not differ significantly among Europe, North and South America, Asia and Africa $(162,163)$.

Squamous cell carcinoma of the head and neck region is traditionally believed and has been shown to be related to environmental factors such as tobacco use and alcohol abuse. However, it has also been shown that a small but significant proportion (15-20\%) of this cancer occur in patients without these traditional risk factors (164). This is further confirmed by the fact that the incidence of oropharyngeal cancer is increasing and tends to occur more in young male patients while the incidence of tobacco use and over all incidence of squamous carcinoma of the head and neck region are decreasing $(158,165)$.

Similar to what occurs with genital HPV related malignancies, HPV positive head and neck squamous carcinoma is related to sexual history. The risk factors include increasing number of oral and vaginal sexual partners, history of genital warts, and younger age at first intercourse $(161,166,167)$. Also, Gillison et al $(167)$ reported increasing association of HPV 16 positive head and neck cancer with increased use of marijuana. While the means by which HPV is transmitted to the upper airways is unclear, it does appear to be related to sexual activity and sexual behaviors - since oral HPV infection is rare in newborn babies of infected mothers and in children prior to sexual activity $(168,169)$. Additional sexual behaviours strongly associated 
with high risk HPV positive tumour include history of oral sex and oral-anal contact $(170,171)$. There is also an increase in individuals with a history of HPV associated anogenital cancers and in husband of women with HPV related in-situ squamous cell carcinoma and invasive cancer (164). Patient with anogenital cancers have a 4.3 fold increase risk of tonsillar cancers and there are remarkable histopathological and molecular biological similarities between HPV tumours at these two sites (172).

HPV-associated head and neck cancer have characteristically distinct features that distinguish them from the non HPV-related head and neck cancers. HPV-related squamous cell carcinoma of head and neck tends to be more common in the oropharyngeal region, and affects men and women equally; unlike tobacco associated cancers that are more frequent in men. HPV-associated cancers patients also tend to be non smokers, non drinkers, and tend to be younger (164). HPV positive head and neck cancer also have distinct histologic appearance. They tend to be more poorly differentiated, non Keratinizing and have basaloid appearance. However, other patterns such as papillary squamous cell carcinoma have also been described (158).

\section{5:4 HPV and Carcinogenesis}

Human papilloma virus (HPV) is a double stranded DNA virus with all putative open reading frames (ORFs) on one DNA strand, and the presumably non coding strand containing short ORFs which are conserved regardless of localization and composition (164). The putative genes consist of early genes (E1-E8) which are expressed shortly after infection and prior to onset of DNA replication, and late genes (L1 \& L2) which code for structural proteins of viral capsids and are activated late during the final stages of the virus circle.

HPVs are epitheliotropic viruses that cause mucocutaneous infections. Currently, more than 200 types are known with about 40 of them having been described to infect human mucosa and the individual types have varying predilections for different epithelial surfaces and different oncogenic potentials (173). Based on their oncogenic potential (ability to cause cancer), they are divided into low risk and high risk types (174). With infection of epithelial cells through abrasions or micro trauma, the virus integrates into the epithelial cells and cause abnormal growth of the cells. The high risk HPV types by virtue of their E7 proteins integrate themselves into the genome of the host epithelial cells, immortalize the cells infected and cause dysregulation of the host cells' cell cycle and apoptosis regulatory proteins and pathways. The high risk HPV types include types 16, 18, 31 33, 35, 39, 45, 51, 52, 56, 58, 59, 66, 68 and 73 (175). HPV types 16 and 18 are responsible for approximately $70 \%$ of all cervical cancers and are also the culprits in the squamous carcinoma of the ano-genital region including vulva, anal, and penile cancers (164). They have also been shown to be the main types involved in HPV related head and neck squamous cell carcinomas (176).

HPV infects the basal cells and the virus early genes E6 and E7 (both of which encode oncoproteins) integrate into the host cell genome. In the actively dividing basal epithelial cells, virus maturation parallels that of the infected host cells as they mature and differentiate into more mature cells. Hence, the early viral genes are found in basal cells and late genes are in the more superficial keratinizing epithelial layer. The E6 protein of the high risk HPV binds to and induces degradation of the tumour suppressor protein p53 (through an ubiquitin- mediated process); resulting in dysregulation of the innate cellular tumour supressor process. The E7 protein of high risk HPV types on the other hand, causes destruction of phosphorylated retinoblastoma proteins mediated transcriptional repression of genes that are involved in regulation of the cell cycle. The combined subcellular (molecular) activities of E6 and E7 proteins of high risk HPV types, results in loss of control of the cell cycle and apoptosis control mechanisms. Thus the infected cells become immortalized and acquire oncogenic potentials that enable them to go into uncontrolled cellular proliferation and tumour formation (177-183). Although integration of the E6 and E7 proteins into the host genome is believed to be central to HPV-mediated carcinogenesis with the integration of HPV DNA into the host genome as the key event, recent studies have shown that transcription of HPV-16E6-E7 mRNA is not necessarily dependent on DNA integration - as the viral DNA which is predominately in episomal (unintegrated) form takes part in the carcinogenesis process $(184,185)$. E6 through binding of p53 and inducing its degradation, impairs host cell apoptosis and causes instability of the host genome (increased predisposition of the genome to mutations and changes that supports cellular proliferation). E6 binding also 
inactivates telomerase (enzyme responsible for maintaining telomeric DNA stability). E7 binding to phosphorylated retinoblastoma proteins and related proteins, results in upregulation of transcriptional factors that activates or turns on genes that regulate cell proliferation. The down regulation of phosphorylated retinoblastoma protein by E7 also result in the upregulation of p16 which is now used as a surrogate marker for HPV infection in squamous cell dysplasia - the histopathologic manifestation of the premalignant transformation of HPV infected cells (186-188)

Fortunately, majority of HPV infection of epithelial cells is self-liming - cleared by the host's humoral and cell mediated immune responses through poorly understood mechanisms (189). However, infection caused by high risk HPV types results in subversion and evasion of the host's virus clearing immune mechanism and persistent infection that may culminate in malignant transformation of infected host cells. It appears that there are other factors in play to initiate the process of carcinogenesis and for the progression through low grade dysplasia to high grade dysplasia and ultimately invasive squamous cell carcinoma. This is supported by report that high risk HPV serotypes are three fold more frequently encountered in patients with malignant lesions than in those with benign or precancerous lesions (190). The precursor lesions of infection by high risk HPV types persist longer and also progress more quickly in individuals infected with these high risk oncogenic viruses compared with those infected by the low risk non oncogenic HPV types $(191,192)$. Hence, the need for typing the HPV detected in individuals that undergo HPV screening. In so doing, individuals at risk would be followed with the appropriate aggressive management scheme; while those infected with less aggressive types are spared unnecessary aggressive management.

Although HPV DNA integration into the host genome results in genomic instability, it is noteworthy that HPV positive cancers tend to have significantly lower levels of chromosomal mutations and loss compared to the HPV negative tumours at the same sites $(191,194)$. Presence and high levels of active HPV infection as demonstrated by elevated levels of p16 in tumour cells, have been shown to be associated with higher survivor rates of $79 \%$ five year survival compared with $20 \%$ five year survival in individuals with HPV negative tumours (195). This improved survival in HPV related squamous cell carcinoma compared with HPV negative tumours has since been confirmed by other studies $(196,197)$. HPV associated head and neck squamous cell carcinoma are more responsive to treatment - being more radiosensitive and have better survivor rates compared to their non HPV-related counterparts. Also, HPV related tumours have been shown to have higher response rate to induction chemotherapy and chemoradiation (198). The higher response to chemotherapy and radiation by HPV associated tumour has been attributed to improved apoptotic response facilitated by the presence of unmutated p53 and absence of other chromosomal abnormalities in HPV related cancers; in contrast to p53 mutation and other chromosomal abnormalities that tend to occur in $\mathrm{HPV}$ negative tumours. Also in HPV negative tumours, the inducing agents such as tobacco and alcohol are known to cause p53 mutation and field cancerization - processes that result in subcellular genetic events that make the tumour cells in those cases to be less radiosensitive and also predispose those individuals to development of a second primary cancer (176). Similar to what obtains with HPV associated head and neck tumours, HPV positive vulva and penile carcinoma also seem to have better prognosis and more favorable therapeutic response in comparison with HPV negative tumours (163).

\section{HUMAN T- CELL LYMPHOTROPHIC VIRUS 1}

\section{6:1 Human T-cell Lymphotrophic Virus Subtypes}

Human T-cell lymphotrophic virus (HLTV) 1 was the first retrovirus to be associated with human disease. It was first isolated and identified in 1980 by Poresz, et al from the T-cells of a patient with cutaneous lymphoma (199). Soon thereafter, Human T-cell lymphotrophic virus type 2 (HLTV2) was isolated from a patient with hairycell leukemia (200). Both HLTV1 and HLTV2 infect helper T-cells and have similar genomic structure with $66 \%$ nucleotide sequence homology in their genome; hence the serologic cross-reactivity between the two. Recently (in 2005), two additional related viruses - HLTV-3 and HTLV-4 were reported in Central Africa (201). However, only HLTV-1 has been shown to have etiological association with a number of diseases (202). There are six subtypes of HLTV-1 (subtypes A-F); but they all appear to have similar pathogenicity (203). 


\section{6:2 HLTV-1 Infections.}

It is estimated that there are about 20 million HLTV-1 infected individuals in the world with the highest prevalence rates in southwestern Japan, sub-Sahara Africa, Caribbean Islands, South America, Papa New Guinea, and Iran (204). The most common mode of transmission is mother-to-child vertical transmission - mostly through breast feeding $(205,206)$ and that has been shown to be directly proportional to the duration of breast feeding and the provirus load in the milk (207-210). Other modes of transmission include sexual contact (211), blood transfusion (212) and sharing of contaminated needles (206). Fortunately, the overwhelming majority (about $90 \%$ ) of individuals infected by HLTV-1 are asymptomatic throughout their lifetime (213). HLTV-1 was originally associated with Adult T-cell leukemia/lymphoma (ATLL), but it has also been associated with the following non neoplastic diseases: uveitis, arthropathy, polymyositis, thyroiditis, Sjögren's syndrome, inflammatory dermatopathic disease conditions, myelopathy and tropical spastic paraparesis $(213,214)$. Some of the inflammatory dermatologic conditions associated with HLTV-1 occur as part of the disease entity called infective dermatitis associated with HLTV1 - a severe and recurrent eczema that is characterized by occurrence in childhood, chronic rhinorrhea and chronic relapsing dermatitis. There is associated infection of the skin and nasal vestibules by nonvirulent Staphylococcus aureus or Beta-hemolytic streptococcus; therefore the dermatitis responds promptly to antibiotic therapy but also recurs promptly on withdrawal of the antibiotic treatment. (215-217). HLTV-1 infected patients are also known to be more predisposed to developing other skin conditions including xerosis, acquired ichthyosis, seborrheic dermatitis, non infectious erythematous dermatitis and infectious skin diseases (dermatophytosis, scabies, verruca vulgaris and bacterial infections) (218-221). The presence of chronic (recurrent and sometimes refractory) skin conditions in HLTV-1 infected patients is thought to result from immune dysregulation and is associated with protracted high levels of cytokines which support the development of lymphoproliferative disorder. Therefore, the presence HLTV-1 associated skin conditions is an indicator for increased risk for developing HLTV-1 associated Leukemia/Lymphoma (222226).

\section{6:3 HLTV1 and ATLL (Pathogenesis)}

Following infection of a T-cell, the proviral DNA (generated from the viral RNA), integrates into the host genome and spreads only as the infected cells divide. Two viral accessory genes tax and HTLV-I b-ZIP factor (HBZ) enhance infectivity by inducing cell proliferation, modulate programmed cell death and induce a series of processes that support cellular transformation and leukemogenesis $(227,228)$. HLTV-1 infection of T-lymphocytes results in T-cell activation and a hyperactive immune response that is characterized by exaggerated type $1 \quad\left(\mathrm{Th}_{1}\right)$ immune response and spontaneous lymphoproliferation with increase in $\mathrm{CD}^{+}$ counts, $\mathrm{CD}^{+}$counts and $\mathrm{CD}^{+} / \mathrm{CD}^{+}$ratio $(215,216,229)$. B-cell activity is also markedly increased resulting in elevation of $\operatorname{Ig} A, \operatorname{Ig} D, \operatorname{Ig}$ $\mathrm{E}$, and Ig G levels $(215,216)$. In the infected cells, the HLTV-1 protein tax also transactivates genes responsible for production of proinflammatory $\mathrm{Th}_{1}$ and $\mathrm{Th}_{2}$ cytokine such as tumour necrosis factor-alpha (TNF $\alpha$ ), interferon-gamma (1FN- $\gamma$ ), interleukin 1, interleukin 5 and interleukin 6 $(214,217,230,231)$.

In HLTV-1 carriers, elevated pro-viral load has been shown to strongly predispose such infected patients to the development of ATLL (232-234) and patients with HLTV-1 associated inflammatory skin conditions tend to have high pro-viral load. In addition, associated bacterial infections results in synergistic stimulation of Tlymphocytes by the bacterial antigens; further worsening exaggeration of the $\mathrm{Th}_{1}$ immune response and associated $\mathrm{T}$-cell proliferation. Eventually, malignant transformation ensues, with the emergence of clones of T-cells that undergo uncontrolled proliferation (214).

ATLL is an aggressive malignant lymphoproliferative disorder with heterogeneous clinical presentation. There are four subtypes, viz; smoldering, chronic, lymphoma and acute types. The lymphoma and acute forms are more aggressive and have worse prognosis with less than 1 year survival after diagnosis (202,213). The incidence of ATLL in HLTV-1-infected is estimated to be less than 5\% (235) and occurs almost exclusively in individuals who acquire the infection with vertical transmission through breast feeding $(202,236)$. ATLL usually occur two to three decades after the onset of HLTV-1 infection. As a result, ATLL is generally reported in adults, and is more common in males $(235,237)$. 
ATLL has variable histopathologic appearances with features similar to those observed in other non HLTV-1 related lymphoproliferative disorders. Therefore, the diagnosis of ATLL is based on criteria that include positive HLTV-1 serology; the presence of hypercalcemia, detection of HTLV-1 pro-viral DNA is tumour cells (in lymphoma type) and the presence of abnormal T-cells in the peripheral

\section{REFERENCES}

1. Epstein MA, Achong BG, Barr YM. Virus particles in cultured lymphoblasts from Burkitt's lymphoma. Lancet. 1964;1:702-3.

2. Henle G, Henle W. Immunofluorescence in cells derived from Burkitt's lymphoma. J Bacteriol. 1966;91:1248-56.

3. Henle G, Henle W, Diehl V. Relation of Burkitt's tumor-associated herpes-type virus to infectious mononucleosis. Proc Natl Acad Sci U S A. 1968;59:94-101.

4. zur Hausen H, Schulte-Holthausen H, Klein G, Henle W, Henle G, Clifford P, Santesson L. EBV DNA in biopsies of Burkitt tumours and anaplastic carcinomas of the nasopharynx. Nature. 197012;228:1056-8.

5. Baumforth KR, Young LS, Flavell KJ, Constandinou C, Murray PG. The Epstein-Barr virus and its association with human cancers. Mol Pathol. 1999;52:307-22.

6. Young LS, Murray PG. Epstein-Barr virus and oncogenesis: from latent genes to tumours. Oncogene. 2003;22:5108-21.

7. Halder S, Murakami M, Verma SC, Kumar P, Yi F, Robertson ES. Early events associated with infection of Epstein-Barr virus infection of primary B-cells. PLoS One. 2009 ;4:e7214.

8. Sixbey JW, Nedrud JG, Raab-Traub N, Hanes RA, Pagano JS. Epstein-Barr virus replication in oropharyngeal epithelial cells. $\mathrm{N}$ Engl J Med. 1984;310:1225-30.

9. Gerber P, Lucas S, Nonoyama M, Perlin E, Goldstein LI. Oral excretion of Epstein-Barr virus by healthy subjects and patients with infectious mononucleosis. Lancet. 1972;2:988-9.

10. Rowe M, Rowe DT, Gregory CD, Young LS, Farrell PJ, Rupani H, Rickinson AB. Differences in B cell growth phenotype reflect novel patterns of Epstein-Barr virus latent gene expression in Burkitt's lymphoma cells. EMBO J. 1987;6:2743-51.

11. Kieff E and Richardson AB. Fields Virology. 4th Eds. Knipe DM and HowleyPM (Eds). Lippincott Williams and Wilkins Publishers: Philadelphia, 2001; pp. 2511-2574

12. Smith P. Epstein-Barr virus complementary strand transcripts (CSTs/BARTs) and cancer. Semin Cancer Biol. 2001;11:469-76. blood (including flower cells) in the leukemic subtypes (202). The flower cells have characteristic polylobulated nuclei and are pathognomonic of ATLL. They are more commonly seen in acute ATLL - and can be readily identified with Giemsa or Wright staining of a blood smear - an attribute that allows for a quick and reliable diagnosis of acute ATLL - even in resources-limited settings (238).

13. Münz C, Moormann A. Immune escape by Epstein-Barr virus associated malignancies. Semin Cancer Biol. 2008;18:381-7.

14. Brady G, MacArthur GJ, Farrell PJ. Epstein-Barr virus and Burkitt lymphoma. J Clin Pathol. 2007;60:1397-402.

15. Young LS, Rickinson AB. Epstein-Barr virus: 40 years on. Nat Rev Cancer. 2004;4:757-68.

16. de Leval L, Hasserjian RP. Diffuse large B-cell lymphomas and burkitt lymphoma. Hematol Oncol Clin North Am. 2009;23:791-827.

17. Bellan C, Stefano L, Giulia de F, Rogena EA, Lorenzo L. Burkitt lymphoma versus diffuse large B-cell lymphoma: a practical approach. Hematol Oncol. 2010;28:53-6.

18. Lam KM, Syed N, Whittle H, Crawford DH Circulating Epstein-Barr virus-carrying B cells in acute malaria. Lancet. 1991;337:876-8.

19. Moormann AM, Heller KN, Chelimo K, Embury P, Ploutz-Snyder R, Otieno JA, Oduor M, Münz C, Rochford R. Children with endemic Burkitt lymphoma are deficient in EBNA1-specific IFNgamma $\mathrm{T}$ cell responses. Int $\mathrm{J}$ Cancer. $2009 ; 124: 1721-6$

20. Küppers R. B cells under influence: transformation of B cells by Epstein-Barr virus. Nat Rev Immunol. 2003;3:801-12.

21. Herbst H, Niedobitek G, Kneba M, Hummel M, Finn T, Anagnostopoulos I, Bergholz M, Krieger G, Stein H. High incidence of Epstein-Barr virus genomes in Hodgkin's disease. Am J Pathol. 1990;137:13-8.

22. Wu TC, Mann RB, Charache P, Hayward SD, Staal $\mathrm{S}$, Lambe BC, Ambinder RF. Detection of EBV gene expression in Reed-Sternberg cells of Hodgkin's disease. Int J Cancer. 1990;46:801-4.

23. Chang KL, Albújar PF, Chen YY, Johnson RM, Weiss LM. High prevalence of Epstein-Barr virus in the Reed-Sternberg cells of Hodgkin's disease occurring in Peru. Blood. 1993;81:496-501.

24. Weinreb M, Day PJ, Niggli F, Green EK, Nyong'o AO, Othieno-Abinya NA, Riyat MS, Raafat F, Mann JR. The consistent association between Epstein-Barr virus and Hodgkin's disease in children in Kenya. Blood. 1996;87:3828-36. 
25. Gutensohn N, Cole P. Epidemiology of Hodgkin's disease. Semin Oncol. 1980;7:92-102.

26. Levine $\mathrm{PH}$, Ablashi DV, Berard CW, Carbone PP, Waggoner DE, Malan L. Elevated antibody titers to Epstein-Barr virus in Hodgkin's disease. Cancer. 1971;27:416-21.

27. Mueller N, Evans A, Harris NL, Comstock GW, Jellum E, Magnus K, Orentreich N, Polk BF, Vogelman J. Hodgkin's disease and Epstein-Barr virus. Altered antibody pattern before diagnosis. N Engl J Med. 1989;320:689-95.

28. Anagnostopoulos I, Herbst H, Niedobitek G, Stein $H$. Demonstration of monoclonal EBV genomes in Hodgkin's disease and Ki-1-positive anaplastic large cell lymphoma by combined Southern blot and in situ hybridization. Blood. 1989;74:810-6.

29. Jarrett RF, Gallagher A, Jones DB, Alexander FE, Krajewski AS, Kelsey A, Adams J, Angus B, Gledhill S, Wright DH, et al. Detection of EpsteinBarr virus genomes in Hodgkin's disease: relation to age. J Clin Pathol. 1991;44:844-8.

30. Armstrong AA, Alexander FE, Cartwright R, Angus B, Krajewski AS, Wright DH, Brown I, Lee F, Kane E, Jarrett RF. Epstein-Barr virus and Hodgkin's disease: further evidence for the three disease hypothesis. Leukemia. 1998;12:1272-6.

31. Pallesen G, Hamilton-Dutoit SJ, Rowe M, Young LS. Expression of Epstein-Barr virus latent gene products in tumour cells of Hodgkin's disease. Lancet. 1991;337:320-2.

32. Murray PG, Young LS, Rowe M, Crocker J. Immunohistochemical demonstration of the Epstein-Barr virus-encoded latent membrane protein in paraffin sections of Hodgkin's disease. J Pathol. 1992;166:1-5.

33. Deacon EM, Pallesen G, Niedobitek G, Crocker J, Brooks L, Rickinson AB, Young LS. Epstein-Barr virus and Hodgkin's disease: transcriptional analysis of virus latency in the malignant cells. J Exp Med. 1993;177:339-49.

34. Herbst H, Foss HD, Samol J, Araujo I, Klotzbach H, Krause H, Agathanggelou A, Niedobitek G, Stein H. Frequent expression of interleukin-10 by Epstein-Barr virus-harboring tumor cells of Hodgkin's disease. Blood. 1996;87:2918-29.

35. Kapp U, Yeh WC, Patterson B, Elia AJ, Kägi D, Ho A, Hessel A, Tipsword M, Williams A, Mirtsos C, Itie A, Moyle M, Mak TW. Interleukin 13 is secreted by and stimulates the growth of Hodgkin and Reed-Sternberg cells. J Exp Med. 1999;189:1939-46.

36. Hsu SM, Lin J, Xie SS, Hsu PL, Rich S. Abundant expression of transforming growth factor-beta 1 and -beta 2 by Hodgkin's Reed-Sternberg cells and by reactive T lymphocytes in Hodgkin's disease. Hum Pathol. 1993;24:249-55.
37. Carbone A, Gloghini A, Dotti G. EBV-associated lymphoproliferative disorders: classification and treatment. Oncologist. 2008;13:577-85.

38. Kelly GL, Milner AE, Baldwin GS, Bell AI, Rickinson AB. Three restricted forms of EpsteinBarr virus latency counteracting apoptosis in cmyc-expressing Burkitt lymphoma cells. Proc Natl Acad Sci U S A. 2006;103:14935-40.

39. Hammerschmidt W, Sugden B. Epstein-Barr virus sustains Burkitt's lymphomas and Hodgkin's disease. Trends Mol Med. 2004;10:331-6.

40. Bubman D, Guasparri I, Cesarman E. Deregulation of c-Myc in primary effusion lymphoma by Kaposi's sarcoma herpesvirus latency-associated nuclear antigen. Oncogene. 2007;26:4979-86.

41. Wei WI, Sham JS. Nasopharyngeal carcinoma. Lancet. 2005;365:2041-54.

42. Heussinger N, Büttner M, Ott G, Brachtel E, Pilch BZ, Kremmer E, Niedobitek G. Expression of the Epstein-Barr virus (EBV)-encoded latent membrane protein 2A (LMP2A) in EBV-associated nasopharyngeal carcinoma. J Pathol. 2004;203:6969.

43. Guo X, Johnson RC, Deng H, Liao J, Guan L, Nelson GW, Tang M, Zheng Y, de The G, O'Brien SJ, Winkler CA, Zeng Y. Evaluation of nonviral risk factors for nasopharyngeal carcinoma in a high-risk population of Southern China. Int J Cancer. 2009;124:2942-7.

44. Raab-Traub N, Flynn K. The structure of the termini of the Epstein-Barr virus as a marker of clonal cellular proliferation. Cell. 1986;47:883-9.

45. Klein G. The relationship of the virus to nasopharyngeal carcinoma. In: Epstein MA, Achong BG, eds. The Epstein-Barr virus. Berlin: Springer-Verlag, 1979:339-50.

46. Weiss LM, Movahed LA, Butler AE, Swanson SA, Frierson HF Jr, Cooper PH, Colby TV, Mills SE. Analysis of lymphoepithelioma and lymphoepithelioma-like carcinomas for EpsteinBarr viral genomes by in situ hybridization. Am J Surg Pathol. 1989;13:625-31.

47. Niedobitek G, Hansmann ML, Herbst H, Young LS, Dienemann D, Hartmann CA, Finn T, Pitteroff S, Welt A, Anagnostopoulos I, et al. Epstein-Barr virus and carcinomas: undifferentiated carcinomas but not squamous cell carcinomas of the nasopharynx are regularly associated with the virus. J Pathol. 1991;165:17-24.

48. Young LS, Dawson CW, Clark D, Rupani H, Busson P, Tursz T, Johnson A, Rickinson AB. Epstein-Barr virus gene expression in nasopharyngeal carcinoma. J Gen Virol. 1988;69 ( Pt 5):1051-65. 
49. Niedobitek G, Young LS, Sam CK, Brooks L, Prasad U, Rickinson AB. Expression of EpsteinBarr virus genes and of lymphocyte activation molecules in undifferentiated nasopharyngeal carcinomas. Am J Pathol. 1992;140:879-87.

50. Zheng X, Yan L, Nilsson B, Eklund G, Drettner B. Epstein-Barr virus infection, salted fish and nasopharyngeal carcinoma. A case-control study in southern China. Acta Oncol. 1994;33:867-72.

51. Mazeron MC. [Value of anti-Epstein-Barr antibody detection in the diagnosis and management of undifferentiated carcinoma of the nasopharynx]. Bull Cancer Radiother. 1996;83:3-7.

52. Hu B, Hong G, Li Z, Xu J, Zhu Z, Li L. Expression of VCA (viral capsid antigen) and EBNA1 (Epstein-Barr-virus-encoded nuclear antigen 1) genes of Epstein-Barr virus in Pichia pastoris and application of the products in a screening test for patients with nasopharyngeal carcinoma. Biotechnol Appl Biochem. 2007;47(Pt 1):59-69.

53. Li S, Deng $Y$, Li X, Chen QP, Liao XC, Qin X. Diagnostic value of Epstein-Barr virus capsid antigen-IgA in nasopharyngeal carcinoma: a metaanalysis. Chin Med J (Engl). 2010;123:1201-5.

54. Mitarnun W, Suwiwat S, Pradutkanchana J, Saechan V, Ishida T, Takao S, Mori A. Epstein-Barr virus-associated peripheral T-cell and NK-cell proliferative disease/lymphoma: clinicopathologic, serologic, and molecular analysis. Am J Hematol. 2002;70:31-8.

55. Rezk SA, Weiss LM. Epstein-Barr virus-associated lymphoproliferative disorders. Hum Pathol. 2007;38:1293-304.

56. Niedobitek G and Young LS. Non-Hodgkin's Lymphomas. 2nd edn. Magrath I (ed). Edward Arnold:London, 1997:pp. 309-329.

57. Akiba S, Koriyama C, Herrera-Goepfert R, Eizuru Y. Epstein-Barr virus associated gastric carcinoma: epidemiological and clinicopathological features. Cancer Sci. 2008;99:195-201.

58. Shibata D, Weiss LM. Epstein-Barr virusassociated gastric adenocarcinoma. Am J Pathol. 1992;140:769-74.

59. Levine $\mathrm{PH}$, Stemmermann $\mathrm{G}$, Lennette ET, Hildesheim A, Shibata D, Nomura A. Elevated antibody titers to Epstein-Barr virus prior to the diagnosis of Epstein-Barr-virus-associated gastric adenocarcinoma. Int J Cancer. 1995;60:642-4.

60. Tokunaga M, Land CE, Uemura $\mathrm{Y}$, Tokudome $\mathrm{T}$, Tanaka S, Sato E. Epstein-Barr virus in gastric carcinoma. Am J Pathol. 1993;143:1250-4.

61. Fukayama M, Hayashi Y, Iwasaki Y, Chong J, Ooba T, Takizawa T, Koike M, Mizutani S, Miyaki M, Hirai K. Epstein-Barr virus-associated gastric carcinoma and Epstein-Barr virus infection of the stomach. Lab Invest. 1994;71:73-81.

62. Imai $S$, Koizumi $S$, Sugiura $M$, Tokunaga $M$, Uemura Y, Yamamoto N, Tanaka S, Sato E, Osato T. Gastric carcinoma: monoclonal epithelial malignant cells expressing Epstein-Barr virus latent infection protein. Proc Natl Acad Sci U S A. 1994;91:9131-5.

63. Fukayama M. Epstein-Barr virus and gastric carcinoma. Pathol Int. 2010;60:337-50

64. Uozaki H, Fukayama M. Epstein-Barr virus and gastric carcinoma-viral carcinogenesis through epigenetic mechanisms. Int J Clin Exp Pathol. 2008;1:198-216.

65. Murphy G, Pfeiffer R, Camargo MC, Rabkin CS. Meta-analysis shows that prevalence of EpsteinBarr virus-positive gastric cancer differs based on sex and anatomic location. Gastroenterology. 2009;137:824-33.

66. Lee JH, Kim SH, Han SH, An JS, Lee ES, Kim YS. Clinicopathological and molecular characteristics of Epstein-Barr virus-associated gastric carcinoma: a meta-analysis. J Gastroenterol Hepatol. 2009;24:354-65.

67. Chang MS, Uozaki H, Chong JM, Ushiku T, Sakuma K, Ishikawa S, Hino R, Barua RR, Iwasaki Y, Arai K, Fujii H, Nagai H, Fukayama M. CpG island methylation status in gastric carcinoma with and without infection of Epstein-Barr virus. Clin Cancer Res. 2006;12:2995-3002.

68. Tsai WL, Chung RT. Viral hepatocarcinogenesis. Oncogene. 2010;29:2309-24.

69. Di Bisceglie AM. Hepatitis B and hepatocellular carcinoma. Hepatology. 2009;49(5 Suppl):S56-60.

70. Yang JD, Roberts LR. Epidemiology and management of hepatocellular carcinoma. Infect Dis Clin North Am. 2010;24:899-919.

71. Perz JF, Armstrong GL, Farrington LA, Hutin YJ, Bell BP. The contributions of hepatitis B virus and hepatitis $C$ virus infections to cirrhosis and primary liver cancer worldwide. J Hepatol. 2006;45:529-38.

72. Beasley RP, Hwang LY, Lin CC, Chien CS. Hepatocellular carcinoma and hepatitis B virus. A prospective study of 22707 men in Taiwan. Lancet. 1981;2(8256):1129-33.

73. Evans AA, Chen G, Ross EA, Shen FM, Lin WY, London WT. Eight-year follow-up of the 90,000person Haimen City cohort: I. Hepatocellular carcinoma mortality, risk factors, and gender differences. Cancer Epidemiol Biomarkers Prev. 2002;11:369-76.

74. Chen CJ, Yang HI, Su J, Jen CL, You SL, Lu SN, Huang GT, Iloeje UH; REVEAL-HBV Study 
Group. Risk of hepatocellular carcinoma across a biological gradient of serum hepatitis B virus DNA level. JAMA. 2006;295:65-73.

75. Chan HL, Hui AY, Wong ML, Tse AM, Hung LC, Wong VW, Sung JJ. Genotype C hepatitis B virus infection is associated with an increased risk of hepatocellular carcinoma. Gut. 2004;53:1494-8.

76. Yang HI, Lu SN, Liaw YF, You SL, Sun CA, Wang LY, Hsiao CK, Chen PJ, Chen DS, Chen CJ; Taiwan Community-Based Cancer Screening Project Group. Hepatitis B e antigen and the risk of hepatocellular carcinoma. N Engl J Med. 2002;347:168-74.

77. Ding X, Mizokami M, Yao G, Xu B, Orito E, Ueda R, Nakanishi M. Hepatitis B virus genotype distribution among chronic hepatitis B virus carriers in Shanghai, China. Intervirology. 2001;44:43-7.

78. Liang TJ, Mok KT, Liu SI, Huang SF, Chou NH, Tsai CC, Chen IS, Yeh MH, Chen YC, Wang BW. Hepatitis B genotype C correlated with poor surgical outcomes for hepatocellular carcinoma. J Am Coll Surg. 2010;211:580-6.

79. Livingston SE, Simonetti JP, McMahon BJ, Bulkow LR, Hurlburt KJ, Homan CE, Snowball MM, Cagle HH, Williams JL, Chulanov VP. Hepatitis B virus genotypes in Alaska Native people with hepatocellular carcinoma: preponderance of genotype F. J Infect Dis. 2007;195:5-11.

80. Fung J, Lai CL, Yuen MF. Hepatitis B and C virusrelated carcinogenesis. Clin Microbiol Infect. 2009;15:964-70.

81. Bonilla Guerrero R, Roberts LR. The role of hepatitis B virus integrations in the pathogenesis of human hepatocellular carcinoma. J Hepatol. 2005;42:760-77.

82. 16: Kew MC, Miller RH, Chen HS, Tennant BC, Purcell RH. Mutant woodchuck hepatitis virus genomes from virions resemble rearranged hepadnaviral integrants in hepatocellular carcinoma. Proc Natl Acad Sci U S A. 1993;90:10211-5.

83. Muroyama R, Kato N, Yoshida H, Otsuka M, Moriyama M, Wang Y, Shao RX, Dharel N, Tanaka Y, Ohta M, Tateishi R, Shiina S, Tatsukawa M, Fukai K, Imazeki F, Yokosuka O, Shiratori Y, Omata M. Nucleotide change of codon 38 in the $\mathrm{X}$ gene of hepatitis $B$ virus genotype $C$ is associated with an increased risk of hepatocellular carcinoma. J Hepatol. 2006;45:805-12.

84. Tennant BC, Toshkov IA, Peek SF, Jacob JR, Menne S, Hornbuckle WE, Schinazi RD, Korba BE, Cote PJ, Gerin JL. Hepatocellular carcinoma in the woodchuck model of hepatitis B virus infection. Gastroenterology. 2004 Nov;127(5 Suppl 1):S28393.
85. Kew MC, Hodkinson J, Paterson AC, Song E. Hepatitis-B virus infection in black children with hepatocellular carcinoma. J Med Virol. 1982;9:2017.

86. Caldwell S, Park SH. The epidemiology of hepatocellular cancer: from the perspectives of public health problem to tumor biology. J Gastroenterol. 2009;44 Suppl 19:96-101.

87. El-Serag HB, Rudolph KL. Hepatocellular carcinoma: epidemiology and molecular carcinogenesis. Gastroenterology. 2007;132:255776.

88. Fattovich G. Natural history and prognosis of hepatitis B. Semin Liver Dis. 2003;23:47-58.

89. Bruix J, Sherman M; Practice Guidelines Committee, American Association for the Study of Liver Diseases. Management of hepatocellular carcinoma. Hepatology. 2005;42:1208-36.

90. Donato F, Boffetta P, Puoti M. A meta-analysis of epidemiological studies on the combined effect of hepatitis B and C virus infections in causing hepatocellular carcinoma. Int $\mathrm{J}$ Cancer. 1998;75:347-54.

91. Donato F, Tagger A, Gelatti U, Parrinello G, Boffetta P, Albertini A, Decarli A, Trevisi P, Ribero ML, Martelli C, Porru S, Nardi G. Alcohol and hepatocellular carcinoma: the effect of lifetime intake and hepatitis virus infections in men and women. Am J Epidemiol. 2002 ;155:323-31.

92. Kamegaya Y, Hiasa Y, Zukerberg L, Fowler N, Blackard JT, Lin W, Choe WH, Schmidt EV, Chung RT. Hepatitis $C$ virus acts as a tumor accelerator by blocking apoptosis in a mouse model of hepatocarcinogenesis. Hepatology. 2005;41:660-7.

93. Lerat $\mathrm{H}$, Honda $\mathrm{M}$, Beard MR, Loesch $\mathrm{K}$, Sun J, Yang Y, Okuda M, Gosert R, Xiao SY, Weinman $\mathrm{SA}$, Lemon SM. Steatosis and liver cancer in transgenic mice expressing the structural and nonstructural proteins of hepatitis $C$ virus. Gastroenterology. 2002;122:352-65.

94. Majumder M, Steele R, Ghosh AK, Zhou XY, Thornburg L, Ray R, Phillips NJ, Ray RB. Expression of hepatitis $C$ virus non-structural 5A protein in the liver of transgenic mice. FEBS Lett. 2003;555:528-32.

95. Battaglia S, Benzoubir N, Nobilet S, Charneau P, Samuel D, Zignego AL, Atfi A, Bréchot C, Bourgeade MF. Liver cancer-derived hepatitis $C$ virus core proteins shift TGF-beta responses from tumor suppression to epithelial-mesenchymal transition. PLoS One. 2009;4(2):e4355.

96. Matsuzaki K, Murata M, Yoshida K, Sekimoto G, Uemura Y, Sakaida N, Kaibori M, Kamiyama Y, Nishizawa M, Fujisawa J, Okazaki K, Seki T. Chronic inflammation associated with hepatitis $\mathrm{C}$ 
virus infection perturbs hepatic transforming growth factor beta signaling, promoting cirrhosis and hepatocellular carcinoma. Hepatology. 2007;46:48-57.

97. Lonardo A, Adinolfi LE, Loria P, Carulli N, Ruggiero G, Day CP. Steatosis and hepatitis C virus: mechanisms and significance for hepatic and extrahepatic disease. Gastroenterology. 2004 Feb;126:586-97.

98. Pekow JR, Bhan AK, Zheng H, Chung RT. Hepatic steatosis is associated with increased frequency of hepatocellular carcinoma in patients with hepatitis C-related cirrhosis. Cancer. 2007;109:2490-6.

99. Kato J, Miyanishi K, Kobune M, Nakamura T, Takada K, Takimoto R, Kawano Y, Takahashi S, Takahashi M, Sato Y, Takayama T, Niitsu Y. Longterm phlebotomy with low-iron diet therapy lowers risk of development of hepatocellular carcinoma from chronic hepatitis C. J Gastroenterol. 2007;42:830-6.

100. Fujita N, Takei Y. Iron, hepatitis C virus, and hepatocellular carcinoma: iron reduction preaches the gospel for chronic hepatitis C. J Gastroenterol. 2007;42:923-6.

101. Missiha SB, Ostrowski M, Heathcote EJ. Disease progression in chronic hepatitis C: modifiable and nonmodifiable factors. Gastroenterology. 2008;134:1699-714.

102. Mesri EA, Cesarman E, Boshoff C. Kaposi's sarcoma and its associated herpes virus. Nat Rev Cancer. 2010;10:707-19.

103. Wen KW, Damania B. Kaposi sarcoma-associated herpesvirus (KSHV): molecular biology and oncogenesis. Cancer Lett. 2010;289:140-50.

104. Siegel JH, Janis R, Alper JC, Schutte H, Robbins L, Blaufox MD. Disseminated visceral Kaposi's sarcoma. Appearance after human renal homograft operation. JAMA. 1969;207:1493-6.

105. Lebbé C, Legendre C, Francès C. Kaposi sarcoma in transplantation. Transplant Rev (Orlando). 2008;22:252-61.

106. Centers for Disease Control. Kaposi's sarcoma and Pneumocystis pneumonia among homosexual men--New York City and California. MMWR Morb Mortal Wkly Rep. 1981;30:305-8.

107. Gottlieb GJ, Ragaz A, Vogel JV, Friedman-Kien A, Rywlin AM, Weiner EA, Ackerman AB. A preliminary communication on extensively disseminated Kaposi's sarcoma in young homosexual men. Am J Dermatopathol. 1981;3:111-4.

108. Friedman-Kien AE. Disseminated Kaposi's sarcoma syndrome in young homosexual men. J Am Acad Dermatol. 1981 Oct;5(4):468-71.
109. Casper C, Wald A. The use of antiviral drugs in the prevention and treatment of Kaposi sarcoma, multicentric Castleman disease and primary effusion lymphoma. Curr Top Microbiol Immunol. 2007;312:289-307.

110. Wabinga HR, Parkin DM, Wabwire-Mangen F, Mugerwa JW. Cancer in Kampala, Uganda, in 1989-91: changes in incidence in the era of AIDS. Int J Cancer. 1993;54(1):26-36.

111. Gallo RC. The enigmas of Kaposi's sarcoma. Science. 1998;282(5395):1837-9.

112. Beral V, Peterman TA, Berkelman RL, Jaffe HW. Kaposi's sarcoma among persons with AIDS: a sexually transmitted infection? Lancet. 1990;335(8682):123-8.

113. Parkin DM, Sitas F, Chirenje M, Stein L, Abratt R, Wabinga H. Part I: Cancer in Indigenous Africans-burden, distribution, and trends. Lancet Oncol. 2008;9:683-92.

114. Parkin DM. The global health burden of infectionassociated cancers in the year 2002. Int J Cancer. 2006;118:3030-44

115. Eltom MA, Jemal A, Mbulaiteye SM, Devesa SS, Biggar RJ. Trends in Kaposi's sarcoma and nonHodgkin's lymphoma incidence in the United States from 1973 through 1998. J Natl Cancer Inst. 2002;94:1204-10.

116. Tam HK, Zhang ZF, Jacobson LP, Margolick JB, Chmiel JS, Rinaldo C, Detels R. Effect of highly active antiretroviral therapy on survival among HIV-infected men with Kaposi sarcoma or nonHodgkin lymphoma. Int J Cancer. 2002;98(6):91622.

117. Giraldo G, Beth E, Haguenau F. Herpes-type virus particles in tissue culture of Kaposi's sarcoma from different geographic regions. J Natl Cancer Inst. 1972;49:1509-26.

118. Chang Y, Cesarman E, Pessin MS, Lee F, Culpepper J, Knowles DM, Moore PS. Identification of herpesvirus-like DNA sequences in AIDS-associated Kaposi's sarcoma. Science. 1994 ;266:1865-9.

119. Stallone G, Infante B, Grandaliano G, Schena FP, Gesualdo L. Kaposi's sarcoma and mTOR: a crossroad between viral infection neoangiogenesis and immunosuppression. Transpl Int. 2008;21:82532.

120. Patel RM, Goldblum JR, Hsi ED. Immunohistochemical detection of human herpes virus- 8 latent nuclear antigen-1 is useful in the diagnosis of Kaposi sarcoma. Mod Pathol. 2004;17:456-60.

121. Patel RM, Goldblum JR, Hsi ED. Response to Pantanowitz et al. Regarding our paper on the utility of the detection of HHV-8 LNA-1 by 
immunohistochemistry in the diagnosis of Kaposi's sarcoma. Mod Pathol. 2005;18:1011-2.

122. Mbulaiteye SM, Biggar RJ, Goedert JJ, Engels EA. Immune deficiency and risk for malignancy among persons with AIDS. J Acquir Immune Defic Syndr. 2003;32:527-33.

123. Barozzi P, Luppi M, Facchetti F, Mecucci C, Alù M, Sarid R, Rasini V, Ravazzini L, Rossi E, Festa S, Crescenzi B, Wolf DG, Schulz TF, Torelli G. Posttransplant Kaposi sarcoma originates from the seeding of donor-derived progenitors. Nat Med. 2003;9:554-61.

124. Cesarman E, Chang Y, Moore PS, Said JW, Knowles DM. Kaposi's sarcoma-associated herpesvirus-like DNA sequences in AIDS-related body-cavity-based lymphomas. N Engl J Med. 1995;332:1186-91.

125. Soulier J, Grollet L, Oksenhendler E, Cacoub P, Cazals-Hatem D, Babinet P, d'Agay MF, Clauvel JP, Raphael M, Degos L, et al. Kaposi's sarcomaassociated herpesvirus-like DNA sequences in multicentric Castleman's disease. Blood. 1995;86:1276-80

126. Dupin N, Fisher C, Kellam P, Ariad S, Tulliez M, Franck N, van Marck E, Salmon D, Gorin I, Escande JP, Weiss RA, Alitalo K, Boshoff C. Distribution of human herpesvirus-8 latently infected cells in Kaposi's sarcoma, multicentric Castleman's disease, and primary effusion lymphoma. Proc Natl Acad Sci U S A. 1999;96:4546-51.

127. Ditter, D. KSHV viral latent lifecycle, in: Damania B and Pipas J. (Eds) DNA Tumor Viruses, Springer, 2008.

128. Verma SC, Lan K, Robertson E. Structure and function of latency-associated nuclear antigen. Curr Top Microbiol Immunol. 2007;312:101-36.

129. Rainbow L, Platt GM, Simpson GR, Sarid R, Gao SJ, Stoiber H, Herrington CS, Moore PS, Schulz TF. The 222- to 234-kilodalton latent nuclear protein (LNA) of Kaposi's sarcoma-associated herpesvirus (human herpesvirus 8) is encoded by orf73 and is a component of the latency-associated nuclear antigen. J Virol. 1997;71:5915-21.

130. Friborg J Jr, Kong W, Hottiger MO, Nabel GJ. p53 inhibition by the LANA protein of KSHV protects against cell death. Nature. 1999;402:889-94.

131. Rigoni-Stern, D. Fatti statistici relative alle mallatie cancrosi che servirono de base alla poche cose dette dal cott. Giornale service propr.pathol.terap.ser. 1842;2:507-517.

132. zur Hausen H. Papillomaviruses in the causation of human cancers - a brief historical account. Virology. 2009;384:260-5.
133. Vonka V, Kanka J, Jelinek J, Subrt I, Suchanek A, Havrankova A, Vachal M, Hirsch I, Domorazkova, A., Savadova, H, et al. Prospective study on the relationship between cervical neoplasia and herpes simplex type-2 virus. I. Epidemiological characteristics. Int J Cancer 1984;33:49-60.

134. Vonk V, Kanka J, Hirsch I, Zavadova H, Kremar M, Suchankova A, Resakova D, Broucek J, Press M, Domorazkova E, Svoboda B, Havrankova A, Jelinek J.

Prospective study on the relationship between cervical neoplasia and herpes simplex type-2. II Herpes simplex virus type- 2 antibody presence in sera taken at enrollment. Int J Cancer 1984;33:6166.

135. Gissmann L, DeVilliers E-M, zur Hausen H. Analysis of human genital warts (condylomata acuminata) and other genital tumors for human papillomavirus type 6 DNA. Int J Cancer 1982;29, 143-146.

136. Gissmann L, Wolnik L, Ikenberg H, Koldovsky $\mathrm{U}$, Schnurch HG, zur Hausen $\mathrm{H}$.

Human papillomavirus type 6 and 11 sequences in genital and laryngeal papillomas and in some cervical cancers. Proc. Nat Acad Sci USA 1983;80:560-563.

137. Hildeshein A, Han CL, Brinton LA, Kurman JJ, Schiller JT. Human papillomavirus type 16 and risk of preinvasive and invasive vulvar cancer: results from a seroepidemiological case-control study. Cancer Epidemiol Biomark Prev $1997 ; 6: 807-813$.

138. Hakim AA, Dinh TA. Worldwide impact of the human papillomavirus vaccine. Curr Treat Options Oncol. 2009;10:44-53.

139. Georgieva S, Iordanov V, Sergieva S. Nature of cervical cancer and other HPV - associated cancers. J BUON. 2009;14:391-8.

140. Madsen BS, Jensen HL, van den Brule AJ, Wohlfahrt J, Frisch M. Risk factors for invasive squamous cell carcinoma of the vulva and vagina-population-based case-control study in Denmark. Int J Cancer. 2008;122:2827-34.

141. Rubin MA, Kleter B, Zhou M, Ayala G, Cubilla AL, Quint WG, Pirog EC. Detection and typing of human papillomavirus DNA in pen ile carcinoma: evidence for multiple independent pathways of penile carcinogenesis. Am J Pathol 2001;159:12111218.

142. Bezerra AL, Lopes A, Santiago GH, Ribeiro KC, Latorre M R, Villa LL. Human papillomavirus as a prognostic factor in carcinoma of the penis: analysis of 82 patients treated with amputation and bilateral lymphadenectomy. Cancer 2001;91:2315-2321. 
143. Lont AP, Kroon BK, Horenblas S, Gallee MP, Berkhof J, Meije, CJ, Snijders PJ. Presence of highrisk human papillomavirus DNA in penile carcinoma predicts favorable outcome in survival. Int J Cancer 2006;119:1078-1081.

144. International Agency for Research on Cancer (IARC), 1995. Monographs on the Evaluation of Carcinogenic Risks to Humans. Human Papillomaviruses. Vol. 64. 1995, Lyon, France.

145. Frisch M, Biggar RJ. Aetiological parallel between tonsillar and anogenital squamous-cell carcinomas. Lancet 1999;354:1442-1443.

146. Hoots BE, Palefsky JM, Pimenta JM, Smith JS. Human papillomavirus type distribution in anal cancer and anal intraepithelial lesions. Int J Cancer. 2009;124:2375-83.

147. Smith JS, Backes DM, Hoots BE, Kurman RJ, Pimenta JM. Human papillomavirus typedistribution in vulvar and vaginal cancers and their associated precursors. Obstet Gynecol. 2009;113:917-24.

148. Li N, Franceschi S, Howell-Jones R, Snijders PJ, Clifford GM. Human papillomavirus type distribution in 30,848 invasive cervical cancers worldwide: Variation by geographical region, histological type and year of publication. Int J Cancer. 2011;128:927-35.

149. Sjoeborg KD, Tropé A, Lie AK, Jonassen CM, Steinbakk M, Hansen M, Jacobsen MB, Cuschieri K, Eskild A. HPV genotype distribution according to severity of cervical neoplasia. Gynecol Oncol. 2010;118:29-34.

150. Howell-Jones R, Bailey A, Beddows S, Sargent A, de Silva N, Wilson G, Anton J, Nichols T, Soldan K, Kitchener H; Study Group Collaborators. Multisite study of HPV type-specific prevalence in women with cervical cancer, intraepithelial neoplasia and normal cytology, in England. Br J Cancer. 2010;103:209-16.

151. Nash G, Allen W, Nash S. Atypical lesions of the anal mucosa in homosexual men. JAMA 1986;256:873-876

152. Scheurlen W, Stremlau A, Gissmann L, Hohn D, Zenner HP, zur Hausen $\mathrm{H}$.

Rearranged HPV 16 molecules in an anal and in a laryngeal carcinoma. Int J Cancer 1986;38:671-676.

153. Hill SA, Coghill SB. Human papillomavirus in squamous carcinoma of anus. Lancet 1986;2:1333.

154. Daling JR, Weiss NS, Hislop TG, Maden C, Coates RJ, Sherman KJ, Ashley RL. Beagrie, M, Ryan JA, Corey L,. Sexual practices, sexually transmitted diseases, and the incidence of anal cancer. N. Engl J Med 1987;317:973-977.
155. WHOCT, 2000. Pathology and Genetics of Tumours of the Digestive System. 2000 IARC Press, Lyon.

156. Syrjanen K, Syrjanen S, Lamberg M, Pyrhonen S, Nuttinen J. Morphological and immunohistochemical evidence suggesting human papillomavirus (HPV) involvement in oral squamous cell carcinogenesis. Int J Oral surg 1983;12:418-24.

157. Löning $\mathrm{T}$, Ikenberg $\mathrm{H}$, Becker J, Gissmann L, Hoepfer I, zur Hausen H. Analysis of oral papillomas, leukoplakias, and invasive carcinomas for human papillomavirus type related DNA. J Invest Dermatol. 1985;84:417-20.

158. Stelow EB, Jo VY, Stoler MH, Mills SE. Human papillomavirus-associated squamous cell Carcinoma of the upper aerodigestive tract. Am J Surg Pathol. 2010;34:e15-24

159. Shiboski CH, Schmidt BL, Jordan RC. Tongue and tonsil carcinoma: increasing trends in the U.S. population ages 20-44 years. Cancer. 2005;103:1843-9.

160. Herrero R, Castellsagué X, Pawlita M, Lissowska J, Kee F, Balaram P, Rajkumar T, Sridhar H, Rose B, Pintos J, Fernández L, Idris A, Sánchez MJ, Nieto A, Talamini R, Tavani A, Bosch FX, Reidel U, Snijders PJ, Meijer CJ, Viscidi R, Muñoz N, Franceschi S; IARC Multicenter Oral Cancer Study Group. Human papillomavirus and oral cancer: the International Agency for Research on Cancer multicenter study. J Natl Cancer Inst. 2003;95:177283.

161. Hennessey PT, Westra WH, Califano JA. Human papillomavirus and head and neck squamous cell carcinoma: recent evidence and clinical implications. J Dent Res. 2009;88:300-6.

162. Kreimer AR, Clifford GM, Boyle P. Human papillomavirus types in head and neck squamous cell carcinomas worldwide: a systematic review. Cancer Epidemiol Biomarkers Prev 2005;14:46775 .

163. D'Souza G, Kreimer AR, Viscidi R, Pawlita M, Fakhry C, Koch WM, Westra WH, Gillison ML. Case-control study of human papillomavirus and oropharyngeal cancer. $\mathrm{N}$ Engl $\mathrm{J}$ Med. 2007:356:1944-56.

164. Mannarini L, Kratochvil V, Calabrese L, Gomes Silva L, Morbini P, Betka J, Benazzo M. Human Papilloma Virus (HPV) in head and neck region: review of literature. Acta Otorhinolaryngol Ital. 2009;29:119-26.

165. Sturgis EM, Cinciripine PM. Trends in head an neck cancer incidence in relation to smoking prevalence: an emerging epidemic of human papillomavirus-associated cancers? Cancer 2007;110:1429-1435 
166. Rose Ragin CC, Taioli E. Second primary head and neck tumor risk in patients with cervical cancer - SEER data analysis. Head Neck 2008;30:58-66.

167. Gillison ML, D'Souza G, Westra W, Sugar E, Xiao W, Begum S, et al. Distinct risk factor profiles for human papillomavirus type 16-positive and human papillomavirus type 16-negative head and neck cancers. J Natl Cancer Inst 2008;100:407-20.

168. Watts DH, Koutsky LA, Holmes KK, Goldman D, Kuypers J, Kiviat NB, Galloway DA. Low risk of perinatal transmission of human papillomavirus: results from a prospective cohort study. Am J Obstet Gynecol 1998;178:365-73.

169. Koch A, Hansen SV, Nielsen NM, Palefsky J, Melbye M. HPV detection in children prior to sexual debut. Int J Cancer 1997;73:621-4.

170. Rosenquist K, Wennerberg J, Schildt EB. Oral status, oral infections and some lifestyle factors as risk factors for oral and oropharyngeal squamous cell carcinoma. A population-based case- control study in southern Sweden. Acta Otolaryngol 2005;125:1327-36.

171. Rajkumar $\mathrm{T}$, Sridhar $\mathrm{H}$, Balaram. Oral cancer in Southern India: the influence of body size, diet, infections and sexual practices. Eur J Cancer Prev 2003;12:135-43.

172. Frisch M, Biggar RJ. Aetiological parallel between tonsillar and anogenital squamous-cell carcinomas. Lancet 1999;354:1442-3.

173. Trottier H, Burchell AN. Epidemiology of mucosal human papillomavirus infection and associated diseases. Public Health Genomics. 2009;12:291307,

174. Syrjanen S. Human papillomavirus (HPV) in head and neck cancer. J Clin Virol 2005;32(Suppl 1):S5966.

175. Munoz N, Bosch FX, Castellsague X. Against which human papillomavirus types shall we vaccinate and screen? The international perspective. Int J Cancer 2004;111:278-85.

176. Gillison ML, Koch WM, Capone RB. Evidence for a casual association between human papillomavirus and subset of head and neck cancers. J Natl Cancer Inst 2000;92:709-20.

177. Havre PA, Yuan J, Hedrick L, Cho KR, Glazer PM. P53 Inactivation by HPV16 E6 results in increased mutagenesis in human cells. Cancer Res 1995;55:4420-4.

178. Solinas-Toldo S, Durst M. Lichter P. Specific chromosomal imbalances in human papillomavirus- transfected cells during progression toward immortality. Proc Natl Acad Sci USA 1997;94:3854-9.
179. Heselmeyer K, Schrock E, Du Manoir S, Blegen $\mathrm{H}$, Shah K, Steinbeck R, et al. Gain of chromosome $3 \mathrm{q}$ defines the transition from severe dysplasia invasive carcinoma of the uterine cervix. Proc Natl Acad Sci USA 1996;93:479-84.

180. Longworth MS, Laimins LA. The binding of histone deacetylases and the integrity of zinc finger- like motifs of the e 7 protein are essential for the life cycle of human papillomavirus type 31. J Virol 2004;78-:3533-41.

181. Zhang B, Chgen W, Roman A. The E7 proteins of low- and high-risk human papillomaviruses share the ability to target the pRB family member p130 for degradation. Proc Natl Acad Sci USA 2006;103:437-42.

182. Chen Z, Storthz KA, Shilitoe EJ. Mutations in the long control region of human Papillomavirus DNA in oral cancer cells and their functional consequences. Cancer Res 1997;57:1614-9.

183. Reznikoff CA, Belair C, Savelieva E, Zhai Y, Pfeifer $\mathrm{K}$, Yeager $\mathrm{T}$, et al. Long-term genomestability and minimal genotypic and phenotypic alterations in HPV16 E7-, but not E6-,immortalized human uroepithelial cells. Genes Dev 1994;8:2227-40.

184. Mellin H, Dhlgren L, Munck-Wikland E, Lindholm J, Rabani H, Kalantari M, et al. Human papillomavirus type 16 is episomal and a high viral load may be correlated to better prognosis in tonsillar cancer. Int J Cancer 2002;102:152-8.

185. Van Tine BA, Dao LD, Wu SY, Sonbuchner TM, Lin BY, Zou N, Chiang CM, et al. Human papillomavirus (HPV) origin-binding protein associates with mitotic spindles to enable virus DNA partitioning. Proc Natl Acad Sci USA 2004;101:4030-5.

186. Dijkstra MG, Heideman DA, de Roy SC, Rozendaal L, Berkhof J, van Krimpen K, van Groningen K, Snijders PJ, Meijer CJ, van Kemenade FJ. p16(INK4a) immunostaining as an alternative to histology review for reliable grading of cervical intraepithelial lesions. J Clin Pathol. 2010;63:972-7.

187. Galgano MT, Castle PE, Atkins KA, Brix WK, Nassau SR, Stoler MH. Using biomarkers as objective standards in the diagnosis of cervical biopsies. Am J Surg Pathol. 2010;34:1077-87.

188. Cubilla AL, Lloveras B, Alejo M, Clavero O, Chaux A, Kasamatsu E, Monfulleda N, Tous S, Alemany L, Klaustermeier J, Muñoz N, Quint W, de Sanjose $\mathrm{S}$, Bosch FX. Value of $\mathrm{p} 16(\mathrm{INK})^{4}(\mathrm{a})$ in the pathology of invasive penile squamous cell carcinomas: A report of 202 cases. Am J Surg Pathol. 2011;35:253-61. 
189. Patel S, Chiplunkar S. Host immune responses to cervical cancer. Curr Opin Obstet Gynecol. 2009;21:54-9.

190. Pyeon D, Newton MA, Lambert PF, den Boon JA, Sengupta S, Marsit CJ, et al. Fundamental differences in cell cycle deregulation in human papillomavirus-positive and human papillomavirus negative head/neck and cervical cancers. Cancer Res 2007;67;4605-19.

191. Khan MJ, Castle PE, Lorincz AT, Wacholder S, Sherman M, Scott DR, Rush BB, Glass AG, Schiffman M. The elevated 10-year risk of cervical precancer and cancer in women with human papillomavirus (HPV) type 16 or 18 and the possible utility of type-specific HPV testing in clinical practice. J Natl Cancer Inst. 2005;97:1072-9.

192. Matsumoto K, Oki A, Furuta R, Maeda H, Yasugi T, Takatsuka N, Mitsuhashi A, Fujii T, Hirai Y, Iwasaka T, Yaegashi N, Watanabe Y, Nagai Y, Kitagawa T, Yoshikawa H; for Japan HPV And Cervical Cancer (JHACC) Study Group. Predicting the progression of cervical precursor lesions by human papillomavirus genotyping: A prospective cohort study. Int J Cancer. 2010 Aug 23. [Epub ahead of print]

193. Braakhuis BJ, Snijders PJ, Keune WJ, Meijer CJ, Ruijter-Schippers HJ, Leemans CR, Brakenhoff RH.Genetic patterns in head and neck cancers that contain or lack transcriptionally active human papillomavirus. J Natl Cancer Inst 2004;97:9981006.

194. Smeets SJ, Braakhuis BJ, Abbas S, Snijders PJ, Ylstra B, van de Wiel MA, Meijer

GA, Leemans CR, Brakenhoff RH. Genome-wide DNA copy number alterations in head and neck squamous cell carcinomas with or without oncogene-expressing human papillomavirus. Oncogene 2006;25:2558-2564.

195. Weinberger PM, Yu Z, Haffty BG, Kowalski D, Harigopal M, Brandsma J, Sasaki C,

Joe J, Camp RL, Rimm DL, Psyrri A. Molecular classification identifies a subset of human papillomavirus-associated oropharyngeal cancers with favorable prognosis. J Clin Oncol 2006;24:736-747.

196. Kumar B, Cordell KG, Lee JS, Worden FP, Prince ME, Tran HH, Wolf GT, Urba SG,

Chepeha DB, Teknos TN, Eisbruch A, Tsien CI, Taylor JM, D'Silva NJ, Yang K,

Kurnit DM, Bauer JA, Bradford CR, Carey TE. EGFR, p16, HPV Titer, Bel-xL and p53, sex, and smoking as indicators of response to therapy and survival in oropharyngeal cancer. J Clin Oncol 2008;26:3128-3137.

197. Charfi L, Jouffroy T, de Cremoux P, Le Peltier N, Thioux M, Freneaux P, et al. . Two types of squamous cell carcinoma of the palatine tonsil characterized by distinct etiology, molecular features and outcome. Cancer Lett 2008;260:72-78.

198. Fakhry C, Westra WH, Li S, Cmelak A, Riodge JA, Pinto $\mathrm{H}$, et al. Improved survival of patients with human papillomavirus -positive head and neck squamous cell carcinoma in a prospective clinical trial. J Natl Cancer Inst 2008;100:261-369.

199. Poiesz BJ, Ruscetti FW, Gazdar AF, Bunn PA, Minna JD, Gallo RC. Detection and isolation of type retrovirus particles from fresh and cultured lymphocytes of a patient with cutaneous T-cell lymphoma. Proc Natl Acad Sci U S A. 1980;77:7415-9.

200. Manns A, Blattner WA. The epidemiology of the human T-cell lymphotrophic virus type I and type II: etiologic role in human disease. Transfusion. 1991;31:67-75.

201. Mahieux R, Gessain A. The human HTLV-3 and HTLV-4 retroviruses: new members of the HTLV family. Pathol Biol (Paris). 2009;57:161-6.

202. Bittencourt AL, de Oliveira Mde F. Cutaneous manifestations associated with HTLV-1 infection. Int J Dermatol. 2010;49:1099-110.

203. Ehrlich GD, Andrews J, Sherman MP, Greenberg SJ, Poiesz BJ. DNA sequence analysis of the gene encoding the HTLV-I p21e transmembrane protein reveals inter- and intraisolate genetic heterogeneity. Virology. 1992;186:619-27.

204. Proietti FA, Carneiro-Proietti AB, Catalan-Soares BC, Murphy EL. Global epidemiology of HTLV-I infection and associated diseases. Oncogene. 2005;24:6058-68.

205. Tsuji Y, Doi H, Yamabe T, Ishimaru T, Miyamoto $\mathrm{T}$, Hino S. Prevention of mother-to-child transmission of human T-lymphotropic virus type-I. Pediatrics. $1990 ; 86: 11-7$.

206. Wiktor SZ, Pate EJ, Rosenberg PS, Barnett M, Palmer P, Medeiros D, Maloney EM, Blattner WA. Mother-to-child transmission of human Tcell lymphotropic virus type associated with prolonged breast-feeding. J Hum Virol. 1997 Nov-Dec;1(1):37-44.

207. 9: Hirata M, Hayashi J, Noguchi A, Nakashima K, Kajiyama W, Kashiwagi S, Sawada T. The effects of breastfeeding and presence of antibody to p40tax protein of human $\mathrm{T}$ cell lymphotropic virus type-I on mother to child transmission. Int J Epidemiol. 1992;21:989-94.

208. 10: Oki T, Yoshinaga M, Otsuka H, Miyata $\mathrm{K}$, Sonoda S, Nagata Y. A sero-epidemiological study on mother-to-child transmission of HTLV-I in southern Kyushu, Japan. Asia Oceania J Obstet Gynaecol. 1992;18:371-7.

209. 11: Li HC, Biggar RJ, Miley WJ, Maloney EM, Cranston B, Hanchard B, Hisada M. Provirus load 
in breast milk and risk of mother-to-child transmission of human $\mathrm{T}$ lymphotropic virus type I. J Infect Dis. 2004;190:1275-8.

210. 12: Takezaki T, Tajima K, Ito M, Ito S, Kinoshita K, Tachibana K, Matsushita Y. Short-term breastfeeding may reduce the risk of vertical transmission of HTLV-I. The Tsushima ATL Study Group. Leukemia. 1997;11 Suppl 3:60-2.

211. 13: Khabbaz RF, Darrow WW, Hartley TM, Witte J, Cohen JB, French J, Gill PS, Potterat J, Sikes RK, Reich $\mathrm{R}$, et al. Seroprevalence and risk factors for HTLV-I/II infection among female prostitutes in the United States. JAMA. 1990;263:60-4.

212. 14: Osame M, Janssen R, Kubota H, Nishitani H, Igata A, Nagataki S, Mori M, Goto I, Shimabukuro H, Khabbaz R, et al. Nationwide survey of HTLV-I-associated myelopathy in Japan: association with blood transfusion. Ann Neurol. 1990;28:50-6.

213. 15: Gonçalves DU, Proietti FA, Ribas JG, Araújo MG, Pinheiro SR, Guedes AC, Carneiro-Proietti $\mathrm{AB}$. Epidemiology, treatment, and prevention of human T-cell leukemia virus type 1-associated diseases. Clin Microbiol Rev. 2010;23:577-89.

214. 16: Lee R, Schwartz RA. Human T-lymphotrophic virus type 1-associated infective dermatitis: a comprehensive review. J Am Acad Dermatol. 2011;64:152-60.

215. 17: LaGrenade L, Hanchard B, Fletcher V, Cranston B, Blattner W. Infective dermatitis of Jamaican children: a marker for HTLV-I infection. Lancet. 1990;336:1345-7.

216. 18: La Grenade L, Manns A, Fletcher V, Derm D, Carberry C, Hanchard B, Maloney EM, Cranston B, Williams NP, Wilks R, Kang EC, Blattner WA. Clinical, pathologic, and immunologic features of human T-lymphotrophic virus type I-associated infective dermatitis in children. Arch Dermatol. 1998;134:439-44.

217. 19: Oliveira Mde F, Brites C, Ferraz N, Magalhaes $\mathrm{P}$, Almeida F, Bittencourt AL. Infective dermatitis associated with the human $\mathrm{T}$ cell lymphotropic virus type I in Salvador, Bahia, Brazil. Clin Infect Dis. 2005;40:e90-6.

218. Bittencourt AL, Barbosa HS, Vieira MD, Farré L. Adult T-cell leukemia/lymphoma (ATL) presenting in the skin: clinical, histological and immunohistochemical features of 52 cases. Acta Oncol. 2009;48:598-604.

219. Gonçalves DU, Guedes AC, Proietti AB, Martins ML, Proietti FA, Lambertucci JR; Interdisciplinary HTLV-1/2 Research Group. Dermatologic lesions in asymptomatic blood donors seropositive for human T cell lymphotropic virus type-1. Am J Trop Med Hyg. 2003;68:562-5.
220. Brites C, Weyll M, Pedroso C, Badaró R. Severe and Norwegian scabies are strongly associated with retroviral (HIV-1/HTLV-1) infection in Bahia, Brazil. AIDS. 2002;16:1292-3.

221. Lenzi ME, Cuzzi-Maya T, Oliveira AL, AndradaSerpa MJ, Araújo AQ. Dermatological findings of human T lymphotropic virus type 1 (HTLV-I)associated myelopathy/tropical spastic paraparesis. Clin Infect Dis. 2003;36:507-13.

222. Tsukasaki K, Yamada Y, Ikeda S, Tomonaga M. Infective dermatitis among patients with ATL in Japan. Int J Cancer. 1994;57:293.

223. Hanchard B, LaGrenade L, Carberry C, Fletcher V, Williams E, Cranston B, Blattner WA, Manns A. Childhood infective dermatitis evolving into adult T-cell leukaemia after 17 years. Lancet. 1991;338:1593-4.

224. Mahé A, Meertens L, Ly F, Sow PS, Diop CT, Samb ND, Diop OM, Valensi F, Gessain A. Human T-cell leukaemia/lymphoma virus type 1-associated infective dermatitis in Africa: a report of five cases from Senegal. Br J Dermatol. 2004;150:958-65.

225. Tschachler E, Franchini G. Infective dermatitis: a pabulum for human T-lymphotrophic virus type I leukemogenesis? Arch Dermatol. 1998;134:487-8.

226. Gonçalves DU, Guedes AC, Carneiro-Proietti AB, Lambertucci JR. HTLV-I associated infective dermatitis may be an indolent HTLV-I associated lymphoma. Braz J Infect Dis. 200;4:100-2.

227. Marriott SJ, Semmes OJ. Impact of HTLV-I Tax on cell cycle progression and the cellular DNA damage repair response. Oncogene. 2005;24:598695.

228. Matsuoka M, Green PL. The HBZ gene, a key player in HTLV-1 pathogenesis. Retrovirology. $2009 ; 6: 71$

229. Maloney EM, Hisada M, Palmer P, Brooks K, Pate E, Wiktor SZ, Lagrenade L, Manns A. Human T cell lymphotropic virus type I-associated infective dermatitis in Jamaica: a case report of clinical and biologic correlates. Pediatr Infect Dis J. 2000;19:560-5.

230. Carvalho EM, Bacellar O, Porto AF, Braga S, Galvão-Castro B, Neva F. Cytokine profile and immunomodulation in asymptomatic human $\mathrm{T}$ lymphotropic virus type 1-infected blood donors. J Acquir Immune Defic Syndr. 2001;27:1-6.

231. Van den Hove LE, Vandenberghe P, Van Gool SW, Ceuppens JL, Demuynck H, Verhoef GE, Boogaerts MA. Peripheral blood lymphocyte subset shifts in patients with untreated hematological tumors: evidence for systemic activation of the $\mathrm{T}$ cell compartment. Leuk Res. $1998 ; 22: 175-84$. 
232. Manns A, Miley WJ, Waters D, Hanchard B, Wharfe G, Cranston B, Williams E, Blattner WA. Prognostic significance of quantitative viral markers in adult T-cell leukemia/lymphoma. Blood. 1999;94:372-3.

233. Okayama A, Stuver S, Matsuoka M, Ishizaki J, Tanaka G, Kubuki Y, Mueller N, Hsieh CC, Tachibana N, Tsubouchi H. Role of HTLV-1 proviral DNA load and clonality in the development of adult T-cell leukemia/lymphoma in asymptomatic carriers. Int J Cancer. 2004;110:621-5.

234. Hisada M, Okayama A, Shioiri S, Spiegelman DL, Stuver SO, Mueller NE. Risk factors for adult Tcell leukemia among carriers of human $\mathrm{T}$ lymphotropic virus type I. Blood. 1998;92:3557-61.

235. Shimoyama M. Diagnostic criteria and classification of clinical subtypes of adult T-cell leukaemia-lymphoma. A report from the Lymphoma Study Group (1984-87). Br J Haematol. 1991;79:428-37.

236. Fujino T, Nagata Y. HTLV-I transmission from mother to child. J Reprod Immunol. 2000;47:197206.

237. Pawson R, Richardson DS, Pagliuca A, Kelsey SM, Hoque S, Breuer J, Newland AC, Mufti GJ. Adult T-cell leukemia/lymphoma in London: clinical experience of 21 cases. Leuk Lymphoma. 1998;31:177-85.

238. Santos JB, Farré L, Batista Eda S, Santos HH, Vieira MD, Bittencourt AL. The importance of flower cells for the early diagnosis of acute adult T-cell leukemia/lymphoma with skin involvement. Acta Oncol. 2010;49:265-7. 